\title{
TRANSFER PRICING OR FORMULA APPORTIONMENT? TAX-INDUCED DISTORTIONS OF MULTINATIONALS' INVESTMENT AND PRODUCTION DECISIONS
}

\author{
JAN THOMAS MARTINI \\ RAINER NIEMANN \\ DIRK SIMONS
}

CESIFO WORKING PAPER NO. 2020

CATEgOry 1: Public FinAnCE

JUNE 2007

An electronic version of the paper may be downloaded

- from the SSRN website:

- from the RePEc website:

www.SSRN.com

- from the CESifo website:

www.RePEc.org

www.CESifo-group.de 


\title{
TRANSFER PRICING OR FORMULA APPORTIONMENT? TAX-INDUCED DISTORTIONS of Multinationals' InVESTMENT AND PRODUCTION DECISIONS
}

\begin{abstract}
For mitigating the problems of transfer pricing formula apportionment (FA) is discussed intensively. However, FA could even be more harmful than transfer pricing because income shifting would require changing economic decisions instead of just taking advantage of accounting options. We analyze the impact of different international tax allocation regimes on a corporate group's investment and production decisions. We show that FA offsets the advantages of decision decentralization as it reverses the separation of responsibilities. It is not clear whether FA is desirable from a fiscal or an entrepreneurial perspective. The effects of FA compared to transfer pricing depend strongly on the parameter setting under consideration, especially the decision procedure within corporate groups.
\end{abstract}

JEL Code: H25, G21, M41.

Keywords: capital budgeting, formula apportionment, international taxation, investment incentives, multinational groups, transfer pricing.

Jan Thomas Martini

Department of Business Administration and

Economics

University of Bielefeld

P.O. Box 100131

33501 Bielefeld

Germany

tmartini@wiwi.uni-bielefeld.de
Rainer Niemann

Institute of Accounting and Taxation

University of Graz

Universitaetsstr. 15 / FE

$8010 \mathrm{Graz}$

Austria

niemann@uni-graz.at

Dirk Simons

Business School

University of Mannheim

Schloss

68131 Mannheim

Germany

simons@bwl.uni-mannheim.de 


\section{Introduction}

From an economic perspective, the integration of financial and product markets is ubiquitous. This can be inferred e.g. from increased transaction volumes on international goods and capital markets. ${ }^{1}$ Multinational groups (MNGs) account for a substantial fraction of this global industrial output and trade. For instance, for the U.S. economy at least $41 \%$ of international goods trades are related party sales. ${ }^{2}$ Consequently, a major challenge for MNGs is to co-ordinate decisions of several subsidiaries located in different countries. Empirical evidence suggests that transfer prices (TPs) are widely used for separating complex decisions and delegating the responsibility for the resulting subproblems to several decision makers. ${ }^{3}$ Apart from the co-ordination function transfer pricing is also deployed for tax purposes. Legally independent group members realize intra-group sales and contribute to a single final product. As a consequence, taxable group profits are frequently allocated among the participating companies by means of transfer prices. Thus, from the group's perspective, transfer pricing is also an important device of international tax planning. By adjusting transfer prices, MNGs can shift their profits to low-tax legislations and reduce the group's overall tax burden. In accordance with this reasoning, in intra-firm contexts transfer pricing concentrates on co-ordination, whereas in inter-firm contexts tax considerations also play an important role.

From the fiscal perspective, tax legislation is still a national responsibility. Until now, the degree of international tax harmonization is negligible. Cross-border transactions are taxed in accordance with unilateral tax laws or bilateral double taxation treaties which assign the right to tax corporate profits. The problem of allocating group profits resulting from joint operations has been solved by transfer prices based on the arm's length principle. This means that fiscal authorities accept transfer prices only if they reflect prices which non-related parties would agree upon. There exist various methods for operationalizing the arm's length principle. Empirically, the most frequently used methods are the cost-plus method, the comparable uncontrolled price method, and the resale price method. However, since an external market for intermediate products often does not exist, even these generally accepted methods show inherent discretion. Because of that national tax authorities have to be aware of potential misuse.

From a political perspective, concern about tax tourism is growing, especially in the EU. Here, the problem has become severe since the mid-European countries joined the

\footnotetext{
${ }^{1}$ See, e.g., van Helleman/Slomp (2002, p. 214) or Simmons (2001, p. 589).

${ }^{2}$ See U.S. Department of Commerce (2006).

${ }^{3}$ See Tang $(2002$, p. 42$)$.
} 
EU. Due to the emerging large tax rate differentials, tax revenues of high-tax legislations eroded. As a consequence, a discussion arose whether transfer pricing should be replaced by formula apportionment (FA). Inspired by the U.S. example and even prior to the tax reform proposals by the European Commission (2001), McLure/Weiner (2000) raise the question whether FA should be implemented in the EU. Under FA, a common tax base is calculated and divided among the host countries in accordance with the given apportionment factors. The tax payable is computed by multiplying the apportioned fraction of the common tax base by the unilaterally determined national tax rate. Thus, earnings management fails to shift profits to low-tax legislations because FA - in contrast to TP - does not allow ex post discretion. At first glance, tax base erosion seems to be stopped by the intended change. However, for high-tax legislations FA could even be more harmful than transfer pricing as income shifting under FA would require changing economic decisions instead of just taking advantage of accounting options. In addition to the erosion of tax revenues, capital investment and employment could decrease in high-tax legislations. ${ }^{4}$

Summarizing, the economic development of international market integration adds to the importance of transfer prices as a co-ordination instrument. However, the lack of international tax harmonization increases the importance of transfer prices as a tax planning tool as well. In the light of these requirements transfer pricing could be overloaded, and alternatives like FA should be discussed. However, there may exist countervailing effects of introducing FA. On the one hand, an internationally aligned tax policy could improve economic decisions as it enhances co-ordination by means of transfer pricing. ${ }^{5}$ On the other hand, implementing FA could cause adjustments of investment and production, harming the high-tax legislations and social production efficiency. Empirical findings suggest that MNGs engage in income shifting induced by tax rate differentials, see, e.g., Klassen/Lang/Wolfson (1993), Klassen/Shackelford (1998) for U.S. and Canadian corporations, and Mintz/Smart (2004) for the Canadian case. The empirical results published by Goolsbee/Maydew (2000) indicate that reducing the payroll weight in the apportionment factor could substantially increase employment in the manufacturing sector.

The goal of our paper is to analyze the impact of different international tax allocation regimes on MNG's investment and production decisions. In detail we want to compare the investment and production distortions induced by transfer pricing and those induced

\footnotetext{
${ }^{4}$ See, e.g., Goolsbee/Maydew (2000).

${ }^{5}$ See, e.g., Bucks/Mazerov (1993) who discuss problems of transfer pricing and propose a refined version of FA.
} 
by FA. We point out that the economic consequences caused by FA in contrast to transfer pricing heavily depend on the companies' budgeting and accounting system. Consequently, the overall effects are much harder to predict. For several constellations we explicitly show the impact of FA.

The remainder of our paper is organized as follows: The next section gives a brief review of the related literature on transfer prices and FA. In the third section the model is presented. In Section four we consider the centralized decision setting and Section five is dedicated to decentralized decision making. Both sections start with a tax-free case as a reference; afterwards different international tax allocation regimes are analyzed. The paper concludes with a comparison of solutions and discussing the resulting managerial and tax policy implications.

\section{Literature Review}

Our paper builds upon three strains of the literature: the theory of foreign investments, theoretical foundations of transfer prices as an instrument of co-ordination and tax planning, and considerations on FA as an alternative method of tax allocation.

The theory of foreign investments is reviewed e.g. in Wong (1995). It rationalizes why many groups have subsidiaries not only in their domestic country but in many foreign countries as well. From a corporate point of view, foreign activities are justified because several regions may have comparative advantages in the production of particular goods and services due to professional education, wage level, or access to raw materials, etc. Further, the access to local markets and the performance of after-sales services is enabled or simplified by foreign branches. Lastly, international activities could be motivated by international tax planning, i.e., tax rate differentials are exploited.

The co-ordination function of transfer prices is extensively discussed e.g. in Grabski (1985), Wagenhofer (1994), Anctil/Dutta (1999), Chwolka/Simons (2003), Göx/Schöndube (2004), Martini et al. (2005), Baldenius/Reichelstein (2006), or Lengsfeld/Pfeiffer/ Schiller (2006). The interaction between transfer pricing and compensation systems is analyzed, e.g., in Besanko/Sibley (1991). Similarly, Choi/Day (1998) consider managerial compensation with respect to the relation between transfer pricing and production incentives when divisions of a MNG are located in different countries. Smith (2002) addresses the trade-off between tax minimization and managerial incentives, too. If a single transfer price is used it might happen that the transfer price's ex ante incentive function dominates its ex post tax saving function. In a one-book setting, Mar- 
tini (2006) points to severe inefficiencies due to the dominance of tax considerations. Nielsen/Raimondos-Møller/Schjelderup (2006) prove that decision structures are influenced by tax parameters. For low tax rate differentials decentralized decision procedures may be optimal whereas high tax rate differentials might induce a centralized structure. Finally, Elitzur/Mintz (1996) analyze tax competition under different transfer pricing rules from a public finance perspective.

With respect to transfer prices as a tax planning tool, Samuelson (1982) shows that firms have an incentive to manipulate production and sales to achieve a tax advantage under an arm's length transfer pricing regime. Li/Balachandran (1996) present a transfer pricing model that integrates asymmetric information and taxation. They compare the effects of a tax rate change under a single-price and a dual-price system. Baldenius/Melumad/Reichelstein (2004) as well as Hyde/Choe (2005) consider a two-book setting concentrating on the optimality of transfer prices from the firm's perspective.

Empirical evidence suggests that approximately $75 \%$ of the companies use the same transfer price for tax and coordination purposes, i.e., one-book systems are implemented frequently. ${ }^{6}$ Further, it can be confirmed that cost-based transfer pricing systems are predominant in business practice. A summary of different empirical studies supporting this statement is given in Table $1 .^{7}$ In a more detailed study, it can actually be verified that the predominance of cost-based transfer pricing schemes holds irrespective of the intermediate good or service under consideration. ${ }^{8}$

Because of the obvious abusive potential of transfer pricing, FA has been an important issue for many years in the public finance literature. Seminal papers in this field are Musgrave (1972) who focuses on inter-nation equity in the division of tax bases among source countries and Gordon/Wilson (1986) who find that FA based on three factors creates distortions which would not occur under separate taxation. Anand/Sansing (2000) show that participating countries of a FA area have an incentive to choose different apportionment formulas although social value added would be maximized by a co-ordinated solution. Since FA would imply a major shift in corporate income taxation there are papers on issues like tax competition under FA, see, e.g., Pethig/Wagener (2003), or Wellisch (2004), or the impact of loss offset under FA, see Gérard/Weiner (2003). Gérard (2005) computes equilibrium tax rates for separate accounting and FA under different loss offset regimes.

Several contributions discuss FA and its tax policy implications. Shackelford/Slemrod

\footnotetext{
${ }^{6}$ See Tang (1993) or Ernst \& Young (2001, p. 6).

${ }^{7}$ See Horngren/Datar/Foster (2006, p. 774).

${ }^{8}$ See Ernst \& Young (2001, p. 19).
} 


\begin{tabular}{|c|c|c|c|c|c|c|}
\hline \multicolumn{7}{|c|}{ Domestic transfer pricing methods } \\
\hline Method & $\begin{array}{l}\text { United } \\
\text { States }\end{array}$ & Australia & Canada & Japan & $\begin{array}{c}\text { New } \\
\text { Zealand }\end{array}$ & $\begin{array}{c}\text { United } \\
\text { Kingdom }\end{array}$ \\
\hline Market-based & $26 \%$ & $13 \%$ & $34 \%$ & $34 \%$ & $18 \%$ & $26 \%$ \\
\hline \multicolumn{7}{|l|}{ Cost-based } \\
\hline Variable cost & $3 \%$ & - & $6 \%$ & $2 \%$ & $10 \%$ & $10 \%$ \\
\hline Absorption or full cost & $49 \%$ & - & $37 \%$ & $44 \%$ & $61 \%$ & $38 \%$ \\
\hline Other & $1 \%$ & - & $3 \%$ & - & - & $1 \%$ \\
\hline Total & $53 \%$ & $65 \%$ & $46 \%$ & $46 \%$ & $71 \%$ & $49 \%$ \\
\hline Negotiated & $17 \%$ & $11 \%$ & $18 \%$ & $19 \%$ & $11 \%$ & $24 \%$ \\
\hline Other & $4 \%$ & $11 \%$ & $2 \%$ & $1 \%$ & - & $1 \%$ \\
\hline Total & $\overline{100 \%}$ & $100 \%$ & $100 \%$ & $\overline{100 \%}$ & $100 \%$ & $\overline{100 \%}$ \\
\hline \multicolumn{7}{|c|}{ Multinational transfer pricing methods } \\
\hline & United & & & & New & United \\
\hline Method & States & Australia & Canada & Japan & Zealand & Kingdom \\
\hline Market-based & $35 \%$ & - & $37 \%$ & $37 \%$ & - & - \\
\hline \multicolumn{7}{|l|}{ Cost-based } \\
\hline Variable cost & $0 \%$ & - & $5 \%$ & $3 \%$ & - & - \\
\hline Absorption or full cost & $42 \%$ & - & $26 \%$ & $38 \%$ & - & - \\
\hline Other & $1 \%$ & - & $2 \%$ & - & - & - \\
\hline Total & $43 \%$ & - & $33 \%$ & $41 \%$ & - & E \\
\hline Negotiated & $14 \%$ & - & $26 \%$ & $22 \%$ & - & - \\
\hline Other & $8 \%$ & - & $4 \%$ & - & - & - \\
\hline Total & $\overline{100 \%}$ & - & $\overline{100 \%}$ & $\overline{100 \%}$ & - & $\overline{-}$ \\
\hline
\end{tabular}

Table 1: Use of transfer pricing methods (source: Horngren/Datar/Foster, 2006, p. 774)

(1998) analyze the revenue implications of implementing FA on a federal level in the U.S. They find that using the widespread three-factor formula ("Massachusetts formula") would considerably increase U.S. tax liabilities of U.S.-based MNGs. However, they do not take behavioral changes into account. Observing tax-induced distortions and tax planning opportunities, Fox/Murray/Luna (2005) also discuss alternative income tax structures on the state level and propose adjustments of the traditional three-factor apportionment formula. Current tax practice in the U.S. and in Canada as well as the tax policy implications arising from the allocation of subnational taxes are described by Wildasin (2000).

Referring to the four versions of FA published by the European Commission, an intensive debate took place. The alternative FA designs are compared by Mintz/Weiner (2003). Sørensen (2004) shows that FA would indeed reduce some problems arising under transfer pricing. However, as long as tax rate differentials remain, new distortions 
would emerge. Devereux (2004) generally appreciates the European Commission's proposals and refers to the integration of corporate and personal taxes. Hellerstein/McLure (2004) use U.S. experience to assess the European Commission's reform proposals. They explore difficulties with regard to the apportionment factors. They suggest not to follow the U.S. example. Depending on the choice of the apportionment formula, some transfer pricing problems could remain under FA. Weiner (2002) identifies some technical and political difficulties and concludes that FA could - in the long run - be superior to separate accounting if the EU becomes more integrated.

Other authors are quite skeptical about the implementation of FA in the EU, see, e.g., Russo (2005). Nielsen/Raimondos-Møller/Schjelderup (2003) conclude that a transition from separate accounting to FA would not eliminate the problems of transfer pricing. In contrast, Schäfer/Spengel (2003) prefer FA with reference to the criteria of inter-nation equity and feasibility.

\section{Economic setting}

Since our goal is to analyze the international allocation of taxable profits, we take the empirical facts of divisionalization and internationalization of groups as given in our model. Accordingly, we assume a MNG with subsidiaries in two different countries. The parent company is a management holding with the power to control the two other legally independent companies. ${ }^{9}$ It raises funds for all group members, organizes capital budgeting, determines the world-wide output, and calculates the group's taxable income. In contrast, the subsidiaries are responsible for investment decisions. ${ }^{10}$ They can be distinguished into a downstream subsidiary, $S_{1}$, where the final product is assembled and sold on the external market and an upstream subsidiary, $S_{2}$, where an intermediate product is manufactured. The structure of the firm is summarized in Figure 1.

The product's market price is determined according to the inverse demand function

$$
p(x)=\frac{d}{\sqrt{x}},
$$

where $p$ denotes the market price of the final product and $x>0$ symbolizes the sales quantity. ${ }^{11}$ The constant $d>0$ is a parameter calibrating the market potential. Note,

\footnotetext{
${ }^{9}$ For a definition of control in the sense used throughout this paper see, e.g., IFRS 3.

${ }^{10}$ Although the problem of profit shifting via transfer pricing occurs in the context of international groups, typically, the same may be observed for a single company with branches in several countries.

${ }^{11}$ See Simon (1989, pp. 18) for the attributes of a multiplicative inverse demand function. Here, the
} 


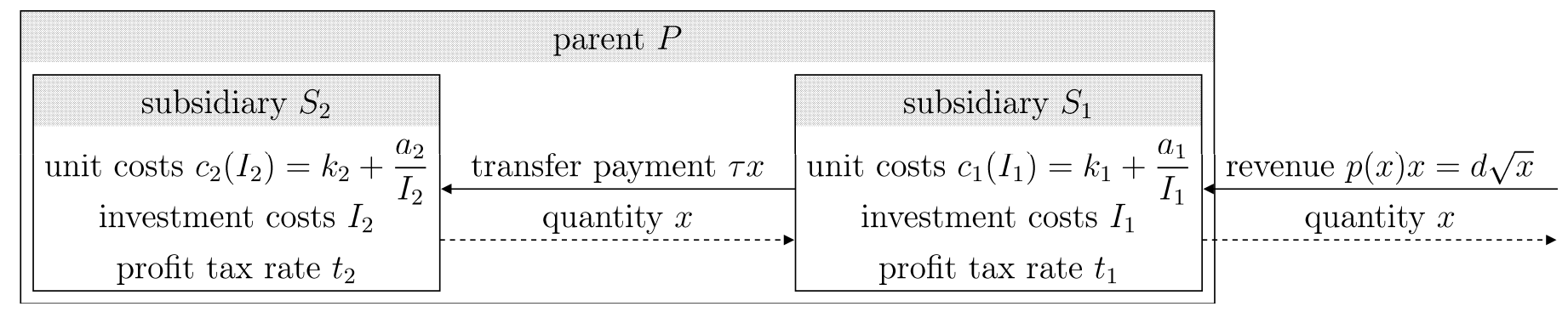

Figure 1: Structure of the firm

that by assumption no storage takes place, i.e., sales equals production quantity. The production costs per unit of the subsidiary $S_{i}$ are given as $c_{i}\left(I_{i}\right), i=1,2$, with

$$
c_{i}\left(I_{i}\right)=k_{i}+\frac{a_{i}}{I_{i}}
$$

According to (2), production costs per unit depend on cost-reducing investments level $I_{i}>0$. The cost reducing effect is scaled by the parameters $a_{i}$ and the lower bound of unit costs is given by the constant $k_{i}>0$. A positive total contribution margin requires at least to assume $d \sqrt{x}>\left(k_{1}+k_{2}\right) x$. Profitable investment and production further require that $d$ is sufficiently large in relation to $a_{1}$ and $a_{2}$. We assume that the sales price, calibrated by parameter $d$, is large enough to guarantee a positive profit. Except for the investment costs $I_{i}$ fixed costs are not taken into account for any of the subsidiaries.

Subsidiary managements are remunerated on the basis of the subsidiaries' profits, whereby intra-group transactions are valued at the transfer price $\tau .{ }^{12}$ The subsidiaries' profits $\Pi_{i}$ are calculated as follows:

$$
\begin{aligned}
& \Pi_{1}\left(I_{1}, x\right)=\left(p(x)-c_{1}\left(I_{1}\right)-\tau\right) x-I_{1} \\
& \Pi_{2}\left(I_{2}, x\right)=\left(\tau-c_{2}\left(I_{2}\right)\right) x-I_{2} .
\end{aligned}
$$

The contribution margin of the downstream subsidiary equals the sales price net of its variable costs. Furthermore, $S_{1}$ has to pay the transfer price $\tau$ per unit of the intermediate product. The upstream subsidiary's revenue is given by the transfer payment received from $S_{1}$ less the production and investment costs. We assume that investment

constant price elasticity is given.

${ }^{12}$ Alternatively, e.g. profit sharing could be practiced. 
outlays are tax-deductible. Summing up, the group's profit $\Pi$ is given by:

$$
\Pi\left(I_{1}, I_{2}, x\right)=\Pi_{1}\left(I_{1}, x\right)+\Pi_{2}\left(I_{2}, x\right)=\left(p(x)-c_{1}\left(I_{1}\right)-c_{2}\left(I_{2}\right)\right) x-I_{1}-I_{2} .
$$

The timing of the model starts with the tax framework as well as the delegation and decision structure of the firm. Since the subsidiaries are located in different countries no group taxation applies and the subsidiaries are taxed separately. Depending on the decision structure a centralized or a decentralized decision procedure applies. In case of centralized planning, the parent company's management, $P$, maximizes the group's profit $\Pi$ by choosing investment levels and production quantity accordingly. This procedure requires the parent company to have detailed and timely information about the market and technology conditions. We assume a sufficient information system to be implemented in the firm. At date 3, production, sales, profits, and taxes are realized. All data become publicly observable and all decision variables are realized as anticipated. Date 2 has to be adapted for the decentralized case. The corresponding timeline is depicted by Figure 3 and discussed later.

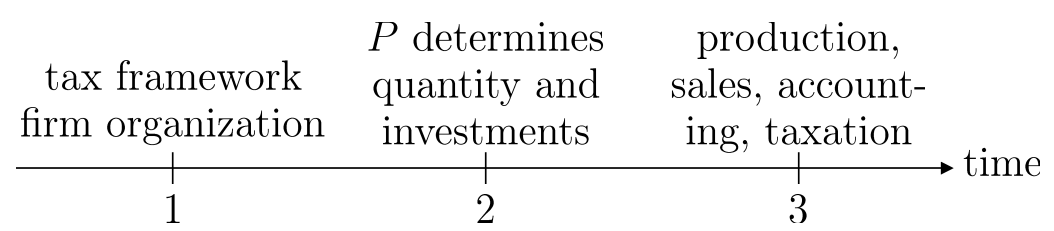

Figure 2: Timeline for the centralized case

Accordingly, the model analysis falls into a centralized (Section 4) and a decentralized (Section 5) planning regime. It is organized as follows: As a first step investment and production decisions are derived under centralization in a tax-free world. In a second step taxation is introduced by considering both TP and FA. Chapter 5 is structured in a similar way but accounts for decentralized planning procedures with various internal accounting structures and tax allocation regimes.

\section{Centralized planning}

\subsection{Centralized planning without taxes}

Centralized planning means that the parent company decides upon investment and production. There is no decision scope for the subsidiaries' managements. In order to prevent that tax effects interfere with other economic variables, we assume identical cost 
structures of the subsidiaries, i.e., $a_{1}=a_{2}=a$ and $k_{1}=k_{2}=k{ }^{13}$ Thus, in a tax-free world, centralized planning using an exogenous transfer price $\tau$ yields the following total profit:

$$
\begin{aligned}
\Pi\left(I_{1}, I_{2}, x\right) & =\left(\frac{d}{\sqrt{x}}-\frac{a}{I_{1}}-k-\tau\right) x-I_{1}+\left(\tau-\frac{a}{I_{2}}-k\right) x-I_{2} \\
& =\left[\left(\frac{d}{\sqrt{x}}-\frac{a}{I_{1}}-k-\tau\right)+\left(\tau-\frac{a}{I_{2}}-k\right)\right] x-\left(I_{1}+I_{2}\right) \\
& =\left(\frac{d}{\sqrt{x}}-\frac{a}{I_{1}}-\frac{a}{I_{2}}-2 k\right) x-\left(I_{1}+I_{2}\right) .
\end{aligned}
$$

Since the transfer price $\tau$ vanishes, centralized planning using an exogenous transfer price is equivalent to a one-step centralized planning according to (5). The optimal investment levels result from equating the partial derivatives of the group's profit function to zero:

$$
\frac{\partial \Pi\left(I_{1}, I_{2}, x\right)}{\partial I_{i}}=\frac{a x}{I_{i}^{2}}-1=0 .
$$

Thus, the optimal investment levels are given by: ${ }^{14}$

$$
I_{1}^{*}=I_{2}^{*}=\sqrt{a x}
$$

Inserting the optimal investment levels in the group's profit function (6) yields:

$$
\Pi(x)=(d-4 \sqrt{a}) \sqrt{x}-2 k x
$$

Maximizing with respect to $x$ gives the unique optimal production quantity:

$$
x^{*}=\left(\frac{d-4 \sqrt{a}}{4 k}\right)^{2} .
$$

\footnotetext{
${ }^{13}$ Nevertheless, different unit costs result from different investment levels.

${ }^{14}$ Throughout the paper, we do not use second-order conditions in our optimization calculus. Instead, we use the following approach: First, we restrict our parameters to cases where positive profits are feasible. Second, boundary solutions, i.e., $x \rightarrow 0, I_{i} \rightarrow 0, x \rightarrow \infty$, or $I_{i} \rightarrow \infty$, yield at best zero profit. Third, as the objective functions are continuously differentiable maximum points are stationary points. Fourth, unique stationary points with positive profits, therefore, are maximum points. Fifth, in (the hypothetical) case of multiple stationary points, all of them have to be checked. In the following, the optimal investment levels are indicated by asterisks.
} 
Hence, the optimal investment levels $I_{i}^{*}$ can be written as:

$$
I_{1}^{*}=I_{2}^{*}=\frac{d \sqrt{a}-4 a}{4 k} .
$$

The optimal group profit $\Pi^{*}$ amounts to:

$$
\Pi^{*}=\frac{(d-4 \sqrt{a})^{2}}{8 k}
$$

\subsection{Centralized planning under separate taxation}

In this section corporate taxation based on arm's length transfer prices is integrated into the model with centralized planning. The subsidiaries' tax rates are symbolized by $t_{i} \in[0,1)$. In this setting all tax parameters are taken into account on an ex ante basis. Hence, the group's after-tax objective function is given by:

$$
\begin{aligned}
\Pi\left(I_{1}, I_{2}, x\right)= & \left(1-t_{1}\right)\left[\left(\frac{d}{\sqrt{x}}-\frac{a}{I_{1}}-k-\tau\right) x-I_{1}\right] \\
& +\left(1-t_{2}\right)\left[\left(\tau-\frac{a}{I_{2}}-k\right) x-I_{2}\right] .
\end{aligned}
$$

The investment decision is not distorted by taxation because the optimality conditions are equivalent to the pre-tax case. The reason for this effect is that the subsidiaries' investment decisions are separable in investments:

$$
\frac{\partial \Pi\left(I_{1}, I_{2}, x\right)}{\partial I_{i}}=\left(1-t_{i}\right)\left(\frac{a x}{I_{i}^{2}}-1\right)=0 .
$$

Accordingly, the optimal investment levels are:

$$
I_{1}^{*}=I_{2}^{*}=\sqrt{a x} .
$$


Substituting the values of (15) into the group's after-tax objective function yields: ${ }^{15}$

$$
\begin{aligned}
\Pi(x)= & \left(1-t_{1}\right)\left[\left(\frac{d}{\sqrt{x}}-\frac{a}{\sqrt{a x}}-k-\tau\right) x-\sqrt{a x}\right] \\
& +\left(1-t_{2}\right)\left[\left(\tau-\frac{a}{\sqrt{a x}}-k\right) x-\sqrt{a x}\right] \\
= & \left(1-t_{1}\right)[d \sqrt{x}-2 \sqrt{a x}-k x-\tau x]+\left(1-t_{2}\right)[\tau x-2 \sqrt{a x}-k x] \\
= & \sqrt{x}\left[\left(1-t_{1}\right) d-\left(2-t_{1}-t_{2}\right) 2 \sqrt{a}\right]-x\left[\left(2-t_{1}-t_{2}\right) k+\left(t_{2}-t_{1}\right) \tau\right] .
\end{aligned}
$$

Differentiating with respect to $x$ gives:

$$
\begin{aligned}
\frac{d \Pi(x)}{d x} & =\frac{\left(1-t_{1}\right) d-\left(2-t_{1}-t_{2}\right) 2 \sqrt{a}}{2 \sqrt{x}}-\left[\left(2-t_{1}-t_{2}\right) k+\left(t_{2}-t_{1}\right) \tau\right]=0 \\
x^{*} & =\left[\frac{\left(1-t_{1}\right) d-\left(2-t_{1}-t_{2}\right) 2 \sqrt{a}}{2\left[\left(2-t_{1}-t_{2}\right) k+\left(t_{2}-t_{1}\right) \tau\right]}\right]^{2} .
\end{aligned}
$$

Inserting $x^{*}$ in the optimal investment levels yields:

$$
I_{i}^{*}=\frac{\left(1-t_{1}\right) d \sqrt{a}-\left(2-t_{1}-t_{2}\right) 2 a}{2\left[\left(2-t_{1}-t_{2}\right) k+\left(t_{2}-t_{1}\right) \tau\right]} .
$$

Although the optimal investment levels differ from the pre-tax case for $t_{1} \neq t_{2}$, investments in both countries always coincide. The optimal total profit $\Pi^{*}$ amounts to:

$$
\Pi^{*}=\frac{\left[\left(1-t_{1}\right) d-\left(2-t_{1}-t_{2}\right) 2 \sqrt{a}\right]^{2}}{4\left[\left(2-t_{1}-t_{2}\right) k+\left(t_{2}-t_{1}\right) \tau\right]} .
$$

As can be inferred from (16) and (17) both the numerator and the denominator of (19) must be positive because otherwise either profit or production quantity would be negative. This implies $\left(2-t_{1}-t_{2}\right) k>\left(t_{1}-t_{2}\right) \tau$, meaning that a net tax shield from the transfer price payment has to be sufficiently small. For $t_{1}>t_{2}$ with sufficiently small tax rate differentials and for $t_{2}>t_{1}$ this condition holds. Yet, (17) may be violated for very large tax rate differentials, i.e., $t_{1} \gg t_{2}$.

In case of identical tax rates, $t_{1}=t_{2}$, the production quantity equals the one of the tax-free world, meaning no distortions occur. In this case, the level of the transfer price has no allocative impact. Obviously, with taxation the net group profit decreases. For

\footnotetext{
${ }^{15}$ There is an ongoing discussion at which stage of the budgeting process tax planning should be integrated. In the given context tax planning should take place on the operational level because the optimal production quantity $x$ may be affected by taxation.
} 
differing tax rates, the optimal production quantity is affected by the transfer price $\tau$, assuming that production cannot be shifted between domestic and foreign production capacities. Differentiating $x^{*}$ with respect to $\tau$ highlights the impact:

$$
\frac{\partial x^{*}}{\partial \tau}=\frac{1}{2} \frac{\left(t_{1}-t_{2}\right)\left[\left(1-t_{1}\right) d-2 \sqrt{a}\left(2-t_{1}-t_{2}\right)\right]}{\left[\left(2-t_{1}-t_{2}\right) k+\left(t_{2}-t_{1}\right) \tau\right]^{3}} .
$$

Intuitively, for $t_{2}>t_{1}\left(t_{1}>t_{2}\right)$ the optimal production quantity decreases (increases) in $\tau$ because increasing $\tau$ means shifting profit to the high-tax (low-tax) country. In the tax-reform discussion the criticism on transfer pricing focused on tax avoidance via profit shifting. Our model proves that a transfer price-based tax regime may cause real economic distortions, too.

\subsection{Centralized planning under formula apportionment}

Currently, MNGs are taxed separately. However, this enables them to shift profits between high-tax and low-tax jurisdictions merely by adjusting the transfer price. From a fiscal perspective, less arbitrary criteria are desirable for tax allocation purposes. Hence, recent EU tax reform proposals foster FA to allocate tax bases between EU member states. Typical criteria are the respective national capital levels, national sum of wages, or national turnover. Interestingly, tax distortions which might be induced by FA have not yet been analyzed extensively. To implement FA it is necessary to define apportionment factors which allocate the world-wide tax base to the respective countries. Since wages and sales are not considered explicitly in our model the only apportionment factor is the capital stock which is given by the investment levels $I_{i}$. Note that due to the one-period setting of our model capital stocks and investment levels coincide. As a consequence, country $i$ receives the fraction $\frac{I_{i}}{I_{1}+I_{2}}$ of the total tax base. Again, we use the tax-free world as a reference case for measuring distortions induced by taxation.

If corporate taxation is based on FA, the group's objective function under centralized planning is given by:

$$
\Pi\left(I_{1}, I_{2}, x\right)=\left(1-\frac{I_{1}}{I_{1}+I_{2}} t_{1}-\frac{I_{2}}{I_{1}+I_{2}} t_{2}\right)\left[\left(\frac{d}{\sqrt{x}}-\frac{a}{I_{1}}-\frac{a}{I_{2}}-2 k\right) x-I_{1}-I_{2}\right] .
$$

The objective function's partial derivatives can be computed explicitly and yield the 
following necessary conditions:

$$
\begin{aligned}
\frac{\partial \Pi\left(I_{1}, I_{2}, x\right)}{\partial I_{1}}= & {\left[\left(\frac{d}{\sqrt{x}}-\frac{a}{I_{1}}-\frac{a}{I_{2}}-2 k\right) x-I_{1}-I_{2}\right] \frac{I_{2}\left(t_{2}-t_{1}\right)}{\left(I_{1}+I_{2}\right)^{2}} } \\
& +\left(\frac{a x}{I_{1}^{2}}-1\right) \frac{\left(1-t_{1}\right) I_{1}+\left(1-t_{2}\right) I_{2}}{I_{1}+I_{2}}=0 \\
\frac{\partial \Pi\left(I_{1}, I_{2}, x\right)}{\partial I_{2}}= & {\left[\left(\frac{d}{\sqrt{x}}-\frac{a}{I_{1}}-\frac{a}{I_{2}}-2 k\right) x-I_{1}-I_{2}\right] \frac{I_{1}\left(t_{1}-t_{2}\right)}{\left(I_{1}+I_{2}\right)^{2}} } \\
& +\left(\frac{a x}{I_{2}^{2}}-1\right) \frac{\left(1-t_{1}\right) I_{1}+\left(1-t_{2}\right) I_{2}}{I_{1}+I_{2}}=0 \\
\frac{\partial \Pi\left(I_{1}, I_{2}, x\right)}{\partial x}= & \left(\frac{d}{2 \sqrt{x}}-\frac{a}{I_{1}}-\frac{a}{I_{2}}-2 k\right) \frac{\left(1-t_{1}\right) I_{1}+\left(1-t_{2}\right) I_{2}}{I_{1}+I_{2}}=0 .
\end{aligned}
$$

Conditions (22)-(24) form a system of non-linear equations for the optimal decisions, which are difficult to solve analytically. Numerical examples in the following section show the effects of FA compared to transfer pricing.

As a first result, we observe that for identical tax rates the optimality conditions (22)-(24) yield - like the TP regime - pre-tax investment and production decisions. For differing tax rates, however, taxation under FA has an effect on investment decisions and indirectly on the production decision. Note that we have the reverse result for the $\mathrm{TP}$ regime. The distorting effect of $\mathrm{FA}$ on investment decisions is easily verified by checking that the pre-tax investments $I_{1}=I_{2}=\sqrt{a x}$ do not solve $(22)-(23)$ for $t_{1} \neq t_{2}$. This result is intuitive since the taxation of total profit depends on the subsidiaries' investments. The rationale of the production decision is not altered by FA as can be inferred from the equivalence of condition (24) to the pre-tax case for given investments. The idea of this result is that the taxation of total profit does not depend on quantity $x$ but total profit does. Observe that this result is conditional on given investment levels so that the distorting effect of FA on investments carries over to the quantity actually chosen.

With respect to optimal investment levels a simple relation can be derived, illustrating that FA establishes an interdependence between domestic and foreign investments. From 
the optimality conditions (22) and (23) the following result emerges:

$$
\begin{aligned}
& \frac{\left[\left(\frac{d}{\sqrt{x}}-\frac{a}{I_{1}}-\frac{a}{I_{2}}-2 k\right) x-I_{1}-I_{2}\right] \frac{I_{2}\left(t_{2}-t_{1}\right)}{\left(I_{1}+I_{2}\right)^{2}}}{\left(\frac{a x}{I_{1}^{2}}-1\right) \frac{\left(1-t_{1}\right) I_{1}+\left(1-t_{2}\right) I_{2}}{I_{1}+I_{2}}} \\
= & \frac{\left[\left(\frac{d}{\sqrt{x}}-\frac{a}{I_{1}}-\frac{a}{I_{2}}-2 k\right) x-I_{1}-I_{2}\right] \frac{I_{1}\left(t_{1}-t_{2}\right)}{\left(I_{1}+I_{2}\right)^{2}}}{\left(\frac{a x}{I_{2}^{2}}-1\right) \frac{\left(1-t_{1}\right) I_{1}+\left(1-t_{2}\right) I_{2}}{I_{1}+I_{2}}} .
\end{aligned}
$$

Simplification of the terms yields:

$$
\frac{I_{1}\left(t_{1}-t_{2}\right)}{\frac{a x}{I_{2}^{2}}-1}=\frac{I_{2}\left(t_{2}-t_{1}\right)}{\frac{a x}{I_{1}^{2}}-1} \Leftrightarrow \frac{a x}{I_{1}}-I_{1}=I_{2}-\frac{a x}{I_{2}} .
$$

Hence, in the optimum the following relation holds:

$$
I_{i}^{*}=\frac{a x^{*}}{I_{j}^{*}}
$$

From the hyperbolic function (27) in connection with (22) several insights can be gained. Firstly, FA does not allow domestic tax authorities to set tax rates irrespective of foreign tax rates as investment distortions occur immediately. Secondly, for rather small tax rate differentials the marginal rate of substitution of investments is close to one, meaning that in high-tax legislations significant investment reactions occur just when their tax rates approaches the low-tax legislations' rates. Put differently, given the existing tax rate differentials between high-tax and low-tax legislations, new investments in low-tax legislations cause only minor investment reductions in high-tax legislations. Thirdly, tax differentials harm economic efficiency, as the first-best condition (7) is only part of (22) and contaminated by other effects. The higher the tax differential the more severe the distortion.

\subsection{Numerical examples for centralized planning}

The numerical examples use the pre-tax situation as a reference case and compare it to transfer pricing and FA under centralized planning. Table 2 summarizes the investment and production effects of both tax regimes for the parameter setting

$$
a=0.2, d=10, k=1, t_{1}=0.5, t_{2}=0.2
$$




\begin{tabular}{lcrrrr}
\hline & & \multicolumn{4}{c}{$\mathrm{TP}$} \\
\cline { 3 - 5 } & pre-tax & $\tau=1.25$ & $\tau=2$ & $\tau=2.15$ & FA \\
\hline$I_{1}$ & 0.918 & 0.928 & 1.226 & 1.310 & 0.605 \\
$I_{2}$ & 0.918 & 0.928 & 1.226 & 1.310 & 1.344 \\
$I_{1}+I_{2}$ & 1.836 & 1.855 & 2.452 & 2.620 & 1.950 \\
$x$ & 4.214 & 4.302 & 7.512 & 8.580 & 4.067 \\
$\Pi$ & 8.428 & 3.980 & 5.259 & 5.620 & 5.750 \\
$p$ & 4.871 & 4.821 & 3.648 & 3.414 & 4.960 \\
$T_{1}$ & 0 & 4.603 & 1.210 & -0.178 & 1.263 \\
$T_{2}$ & 0 & -0.156 & 1.012 & 1.449 & 1.122 \\
$T_{1}+T_{2}$ & 0 & 4.447 & 2.222 & 1.272 & 2.384 \\
$\Pi+T_{1}+T_{2}$ & 8.428 & 8.427 & 7.481 & 6.892 & 8.134 \\
$\left(T_{1}+T_{2}\right) /\left(\Pi+T_{1}+T_{2}\right)$ & 0 & $52.8 \%$ & $29.7 \%$ & $18.5 \%$ & $29.3 \%$ \\
\hline
\end{tabular}

Table 2: Numerical examples for centralized planning

We make the following observations:

1. For both regimes the total investment $I_{1}+I_{2}$ increases compared to the pre-tax case. In accordance with (20) under TP total investment increase monotonically with increasing transfer prices. Whereas the investment levels in both countries always coincide under TP the low-tax country attracts more investment under FA. Depending on the tax rate differential the differences in investment levels may be substantial. ${ }^{16}$ Due to $t_{1}>t_{2}$ the production quantity increases for all TP cases, see again (20). In contrast, it is decreasing for FA compared to the pre-tax case, which reveals tax-induced inefficiencies. FA may even be dominated by TP, as can be inferred from $\tau=1.25$. Here, a higher output is produced under the TP regime compared to FA with lower investments.

2. Tax arbitrage is possible only for the tax regime based on transfer prices. This result follows from a high transfer price $(\tau=2.15)$ in connection with full lossoffset in the high-tax country $\left(t_{1}>t_{2}\right) .{ }^{17}$ Under FA this effect does not arise because total pre-tax profits are assumed to be positive and a tax reimbursement cannot occur. Whereas tax revenue $T_{i}$ is positive under FA for both countries, tax revenues under TP may have different signs.

\footnotetext{
${ }^{16}$ Further FA cases not depicted here show that total investment increases compared to the pre-tax case. The differences can be inferred from (27).

${ }^{17}$ Note that for $\tau=1.25$ a negative tax payment occurs as well. However, it occurs in the low tax legislation meaning that no tax arbitrage is realized.
} 
3. The effects of the tax regime on total profit $\Pi$ are ambiguous. Typically, after-tax profits are lower compared to the pre-tax case. However, under TP there exist extreme cases - violating the arm's length principle and thus not depicted here - in which tax arbitrage raises the after-tax profit above the pre-tax level. As explained above under FA this effect does not occur.

4. The effects of the tax regime on total tax revenue $T_{1}+T_{2}$ are ambiguous and depend on the parameter setting, especially the transfer price. For several constellations, both fiscal administrations may prefer TP with additional transfer payments between the countries compared to FA.

5. The effects of the tax regime on total value added are ambiguous. Total value added is measured as the sum of world-wide tax revenue and after-tax profit, $\Pi+T_{1}+T_{2}$. Of course, both TP and FA fall short of the pre-tax level. Under TP total value added may even be negative for extreme cases of tax arbitrage. In most cases, however, total value added is positive.

6. As expected average tax rates can be manipulated under TP by setting transfer prices accordingly. Under FA the average tax rate is an average of both nominal tax rates weighted with the respective investment proportions. Thus, economic manipulations are required for tax manipulation.

From a fiscal perspective TP might indeed suffer from severe weaknesses. Nevertheless, implementing FA induces ambiguous results from a fiscal as well as from an entrepreneurial perspective if central planning is considered. It is not clear whether implementing FA is advantageous at all.

\section{Decentralized planning}

\subsection{The group's planning procedure}

In this section we assume a decentralized decision procedure. This means that several decision makers are involved. In a typical budgeting process ${ }^{18}$ the operating budget and the financial budget are the key components of the master budget. Starting with the operating budget central figures like revenues, material costs, or R \& D costs are planned. These data enter the financial budgeting process where, amongst others, the capital

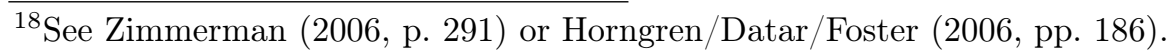


investment budget is defined. However, this procedure is not a linear one, but "the master budget is finalized only after several rounds of discussions between top management and managers responsible for various business functions in the value chain." 19 This decision procedure is represented in a stylized way in Figure 3.

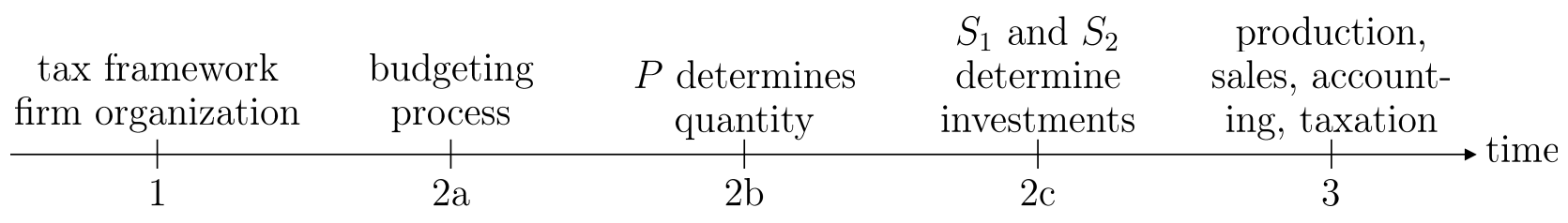

Figure 3: Timeline for the decentralized case

Ex ante decentralized planning deals with information asymmetry between the parent company and the subsidiaries with respect to price and cost data. By handing in their investment proposals the subsidiaries supply the relevant revenue and cost data to the parent company (date 2a). Now, the parent company can decide on the production quantity $x$ (date $2 \mathrm{~b}$ ). Further, as the investment proposals are conditional on the production quantity, the parent company funds the subsidiaries with the required capital. As a result, the investment levels are determined (date 2c). This procedure can be regarded as a combination of bottom-up and top-down planning. The budgeting process resolves this information asymmetry.

Since the budgeting procedure is the result of several rounds of discussion, we assume that no misreporting occurs. This assumption is supported by the parent company's commitment to accept the subsidiaries' investment proposals instead of exploiting the reported information for a full-scale centralized optimization of investment and production. Basically, the investment decisions are delegated to the subsidiaries as a compensation for reporting truthfully. ${ }^{20}$ Due to truth telling, the solutions for decentralized planning remain unchanged for the case without taxes and under separate accounting, as can be inferred from Appendix A and B, see (54) to (66). However, the solutions for FA heavily rely on companies' internal accounting systems as derived in the subsequent sections.

Overall, we analyze four different decentralized settings for FA which can be distinguished with respect to the degree of integration of the two subsidiaries. There exist

\footnotetext{
${ }^{19}$ Horngren/Datar/Foster (2006, p. 186).

${ }^{20}$ Note that truth-telling mechanisms exist in the literature. Since this is beyond the scope of our paper, we assume that some kind of truth-telling mechanism is already implemented. See Groves (1973), Weitzman (1976), Groves/Loeb (1979), Reichelstein/Osband (1984), Osband/Reichelstein (1985), Reichelstein (1992).
} 
two dimensions of integration, namely the internal view considering the integration of the subsidiaries' objective functions and the external view considering spillovers of tax burdens between the subsidiaries. Table 3 depicts the categories of the following FA analysis.

\begin{tabular}{ccc}
\hline & \multicolumn{2}{c}{ External view } \\
\cline { 2 - 3 } Internal view & separated & integrated \\
\hline separated & TP internally, FA for taxation & tax allocation \\
& (Sec. 5.2) & (Sec. 5.4) \\
integrated & profit sharing & full FA \\
& (Sec. 5.3) & (Sec. 5.5) \\
\hline
\end{tabular}

Table 3: Considered cases

In the TP/FA setting the subsidiaries' objective functions are separated by relying on a transfer price. Thus, the investment decisions are not influenced by FA as it is only applied to the group's objective function. Consequently, a shifting of tax burden between the two subsidiaries does not occur. In contrast, the sharing of pre-tax profits leads to an integrated objective function for the subsidiaries (integration from the internal point of view). However, tax burden shifting is not induced as tax payments are still relevant only for the group's decision making. In the tax allocation setting, taxation enters the subsidiaries' investment calculus. Although a transfer price is used in order to separate responsibilities from an internal point of view, the tax allocation regime introduces firmwide tax considerations to the subsidiaries investment decisions. Thus, from an external point of view integration is given. In the last setting, i.e. full FA, integration with respect to both dimensions is given because in fact profit sharing occurs relying on sharing parameters resulting from the FA approach.

\subsection{Decentralized planning with formula apportionment for tax purposes only}

In this section we introduce a tax system based on FA, meaning a joint tax base is computed and distributed among the fiscal authorities via FA. However, the internal objective functions are separated as they still rely on transfer pricing. FA is not applied but on the group level. Consequently, tax considerations are irrelevant for the subsidiaries' 
decisions. The according subsidiaries' profit functions read:

$$
\begin{aligned}
& \Pi_{1}\left(I_{1}\right)=\left(1-t_{1}\right)\left[\left(\frac{d}{\sqrt{x}}-\frac{a}{I_{1}}-k-\tau\right) x-I_{1}\right] \\
& \Pi_{2}\left(I_{2}\right)=\left(1-t_{2}\right)\left[\left(\tau-\frac{a}{I_{2}}-k\right) x-I_{2}\right] .
\end{aligned}
$$

The optimality conditions for the subsidiaries' investment, thus, remain undistorted compared to the pre-tax case, i.e.:

$$
I_{1}^{*}=I_{2}^{*}=\sqrt{a x}
$$

The group's profit function under FA corresponds to (21) under centralized planning:

$$
\Pi\left(I_{1}, I_{2}, x\right)=\left(1-\frac{I_{1}}{I_{1}+I_{2}} t_{1}-\frac{I_{2}}{I_{1}+I_{2}} t_{2}\right)\left[\left(\frac{d}{\sqrt{x}}-\frac{a}{I_{1}}-\frac{a}{I_{2}}-2 k\right) x-I_{1}-I_{2}\right] .
$$

The term in brackets of (31) symbolizes the profit before taxes, which equals the total contribution margin less investment costs. This profit before taxes is the group's worldwide tax base, which is allocated proportional to the subsidiaries' capital stocks. Country 1 receives the fraction $I_{1} /\left(I_{1}+I_{2}\right)$ of the worldwide tax base. The fraction $I_{2} /\left(I_{1}+I_{2}\right)$ belongs to country 2 . Since the subsidiaries' investment levels are identical according to (30), the these shares equal $1 / 2$ in both countries. Hence, total profit (31) gets

$$
\begin{aligned}
\Pi(x) & =\left(1-\frac{t_{1}}{2}-\frac{t_{2}}{2}\right)\left(\left(\frac{d}{\sqrt{x}}-\frac{2 a}{\sqrt{a x}}-2 k\right) x-2 \sqrt{a x}\right) \\
& =\left(1-\frac{t_{1}}{2}-\frac{t_{2}}{2}\right)[(d-4 \sqrt{a}) \sqrt{x}-2 k x] .
\end{aligned}
$$

Determining the optimal production quantity yields:

$$
\begin{aligned}
\frac{d \Pi(x)}{d x} & =\left(1-\frac{t_{1}}{2}-\frac{t_{2}}{2}\right)\left(\frac{d-4 \sqrt{a}}{2 \sqrt{x}}-2 k\right)=0 \\
\sqrt{x} & =\frac{d-4 \sqrt{a}}{4 k} \\
x^{*} & =\left(\frac{d-4 \sqrt{a}}{4 k}\right)^{2} .
\end{aligned}
$$


Accordingly, the optimal investment levels are

$$
I_{1}^{*}=I_{2}^{*}=\frac{d \sqrt{a}-4 a}{4 k},
$$

and the group's optimal profit amounts to:

$$
\Pi^{*}=\left(1-\frac{t_{1}}{2}-\frac{t_{2}}{2}\right) \frac{(d-4 \sqrt{a})^{2}}{8 k} .
$$

Obviously, the optimal production quantity corresponds to the pre-tax case. At first glance, the tax reformers' goal is achieved as a FA-based tax regime seems to be neutral with respect to both production and investment decisions. However, this result strongly depends on the assumption that the subsidiaries' profits internally are still computed using transfer prices. In this case, the decision makers' decision making is not affected by FA elements. Unfortunately, empirical evidence suggests that corporations tend to align managerial and financial accounting. Accordingly, it is necessary to analyze the effects of integrating elements of FA into the subsidiaries' profit functions.

\subsection{Profit sharing as a tax allocation regime}

A first step to align managerial accounting with financial accounting under FA is to derive the subsidiaries' objective functions from a joint profit measure. A simple way of implementing a joint objective function is to use profit sharing. ${ }^{21}$ Note that in this section tax considerations resulting from FA still belong to the group level. Therefore the group's profit corresponds to (21) in the centralized case:

$$
\Pi\left(I_{1}, I_{2}, x\right)=\left(1-\frac{I_{1}}{I_{1}+I_{2}} t_{1}-\frac{I_{2}}{I_{1}+I_{2}} t_{2}\right)\left[\left(\frac{d}{\sqrt{x}}-\frac{a}{I_{1}}-\frac{a}{I_{2}}-2 k\right) x-I_{1}-I_{2}\right] .
$$

Each subsidiary $S_{i}$ accounts for a given fraction $\varepsilon_{i}>0$ of the jointly generated pre-tax profit, i.e.,

$$
\Pi_{i}\left(I_{1}, I_{2}, x\right)=\varepsilon_{i}\left[\left(\frac{d}{\sqrt{x}}-\frac{a}{I_{1}}-\frac{a}{I_{2}}-2 k\right) x-I_{1}-I_{2}\right]
$$

\footnotetext{
${ }^{21}$ See, e.g., Milgrom/Roberts (1992, pp. 413$)$.
} 
with $\varepsilon_{1}+\varepsilon_{2}=1$. Accordingly, the subsidiaries' investment decisions are undistorted:

$$
\begin{aligned}
\frac{\partial \prod_{i}\left(I_{1}, I_{2}, x\right)}{\partial I_{i}} & =\varepsilon_{i}\left(\frac{a x}{I_{i}^{2}}-1\right)=0 \\
I_{i}^{*} & =\sqrt{a x} .
\end{aligned}
$$

Again, the optimal investment conditions are identical in both countries. Hence,

$$
\begin{aligned}
\Pi(x) & =\left(1-\frac{t_{1}}{2}-\frac{t_{2}}{2}\right)\left(\left(\frac{d}{\sqrt{x}}-\frac{2 a}{\sqrt{a x}}-2 k\right) x-2 \sqrt{a x}\right) \\
& =\left(1-\frac{t_{1}}{2}-\frac{t_{2}}{2}\right)[(d-4 \sqrt{a}) \sqrt{x}-2 k x] .
\end{aligned}
$$

Consequently, the optimal solutions can be inferred from Section 5.2, i.e.:

$$
x^{*}=\left(\frac{d-4 \sqrt{a}}{4 k}\right)^{2}, \quad I_{1}^{*}=I_{2}^{*}=\frac{d \sqrt{a}-4 a}{4 k}, \quad \Pi^{*}=\left(1-\frac{t_{1}}{2}-\frac{t_{2}}{2}\right) \frac{(d-4 \sqrt{a})^{2}}{8 k} .
$$

Obviously, FA combined with internal profit sharing ensures decision scenarios equivalent to the pre-tax case or FA for tax purposes only with transfer pricing for internal control purposes.

\subsection{Allocation of taxes to subsidiaries' profits}

Hitherto, the subsidiaries' decision making does not take FA taxation into account. Consequently, their decisions might not be optimal from the group's perspective. One attempt to remedy this problem is that $P$ effectively integrates taxation into the subsidiaries' objective functions.

This section analyzes a setting in which internal accounting separation via transfer pricing is induced by an allocation of the FA tax burden to the respective subsidiary. More precisely, each subsidiary is charged with a fraction of the total tax burden identical to the corresponding apportionment factor. In our opinion, this is a likely situation given the EU tax reform proposals. For internal control purposes, groups will further rely on national profit \& loss accounts, whereas taxes are not calculated in such detail. Rather, they are simply divided up in the same manner as they are apportioned for tax purposes. Consequently, the subsidiaries' net profits are computed in a hybrid form. The first component comes from individual accounts. The second component is just a push-down allocation of group-wide taxes.

Given the group applies this kind of tax planning severe implications for decentral- 
ization arise. Contrary to the above cases the subsidiaries need information about the other subsidiary's data: FA requires a group-wide perspective on each subsidiary's level. Otherwise, optimizing behavior would not be possible. The downstream subsidiaries' profit function is given by:

$$
\begin{aligned}
\Pi_{1}\left(I_{1}, I_{2}, x\right)= & \left(\frac{d}{\sqrt{x}}-\frac{a}{I_{1}}-k-\tau\right) x-I_{1} \\
& -\frac{t_{1} I_{1}}{I_{1}+I_{2}}\left[\left(\frac{d}{\sqrt{x}}-\frac{a}{I_{1}}-\frac{a}{I_{2}}-2 k\right) x-I_{1}-I_{2}\right] .
\end{aligned}
$$

Differentiating with respect to $I_{1}$ yields:

$$
\begin{aligned}
\frac{\partial \Pi_{1}\left(I_{1}, I_{2}, x\right)}{\partial I_{1}}= & \frac{a x}{I_{1}^{2}}-1 \\
& -\left[\frac{t_{1} I_{1}}{I_{1}+I_{2}}\left(\frac{a x}{I_{1}^{2}}-1\right)+\frac{t_{1} I_{2}\left(d \sqrt{x}-\frac{a x}{I_{1}}-\frac{a x}{I_{2}}-2 k x-I_{1}-I_{2}\right)}{\left(I_{1}+I_{2}\right)^{2}}\right] \\
= & \left(1-\frac{t_{1} I_{1}}{I_{1}+I_{2}}\right)\left(\frac{a x}{I_{1}^{2}}-1\right) \\
& -\frac{t_{1} I_{2}}{\left(I_{1}+I_{2}\right)^{2}}\left(d \sqrt{x}-\frac{a x}{I_{1}}-\frac{a x}{I_{2}}-2 k x-I_{1}-I_{2}\right) .
\end{aligned}
$$

For the upstream subsidiary $S_{2}$ the corresponding objective function is:

$$
\begin{aligned}
\Pi_{2}\left(I_{1}, I_{2}, x\right)= & \left(\tau-\frac{a}{I_{1}}-k\right) x-I_{2} \\
& -\frac{t_{2} I_{2}}{I_{1}+I_{2}}\left(\left(\frac{d}{\sqrt{x}}-\frac{a}{I_{1}}-\frac{a}{I_{2}}-2 k\right) x-I_{1}-I_{2}\right)
\end{aligned}
$$

with

$$
\begin{aligned}
\frac{\partial \Pi_{2}\left(I_{1}, I_{2}, x\right)}{\partial I_{2}}= & \left(1-\frac{t_{2} I_{2}}{I_{1}+I_{2}}\right)\left(\frac{a x}{I_{1}^{2}}-1\right) \\
& -\frac{t_{2} I_{1}}{\left(I_{1}+I_{2}\right)^{2}}\left(d \sqrt{x}-\frac{a x}{I_{1}}-\frac{a x}{I_{2}}-2 k x-I_{1}-I_{2}\right) .
\end{aligned}
$$

From (43) and (45) it can be seen that the derivatives contain the first-best optimality condition (7). However, by subtracting the second term, the optimal investment levels will be reduced. The reason for this decrease is that the higher a subsidiary's investment the higher the fraction of the world-wide tax base which is allocated to it. In contrast 
to the previous sections, the subsidiaries' investment levels are inter-dependent, which is caused by the apportionment factor. Consequently, the intended autonomy of the subsidiary managers is offset as they have to take into consideration the investment calculus of the other manager. Hence, the subsidiaries' investments have to be coordinated.

In principle, there exist analytical solutions for the stationary points of (43) and (45) yielding equilibrium investments. However, these are too complicated for useful economic interpretations, ${ }^{22}$ even for identical tax rates. See Appendix C for a numerical solution approach.

\subsection{Full formula apportionment regime}

Full alignment of managerial and financial accounting is achieved when FA is used for both internal profit allocation among subsidiaries and for taxation. From the internal as well as from the external perspective the subsidiaries' objective functions then are integrated. We call this scenario full FA.

Under full FA the joint profit $\Pi\left(I_{1}, I_{2}, x\right)$ given by

$$
\Pi\left(I_{1}, I_{2}, x\right)=\left(\frac{d}{\sqrt{x}}-\frac{a}{I_{1}}-\frac{a}{I_{2}}-2 k\right) x-I_{1}-I_{2}
$$

is allocated to subsidiary $S_{i}$ according to the apportionment factor $I_{i} / I_{1}+I_{2}$ and taxed at the national tax rate $t_{i}$. For subsidiary $S_{i}$ this leads to the following profit function:

$$
\Pi_{i}\left(I_{1}, I_{2}, x\right)=\left(1-t_{i}\right) \frac{I_{i}}{I_{1}+I_{2}}\left[\left(\frac{d}{\sqrt{x}}-\frac{a}{I_{1}}-\frac{a}{I_{2}}-2 k\right) x-I_{1}-I_{2}\right] .
$$

From this objective function it follows immediately that the tax rates $t_{1}$ and $t_{2}$ are

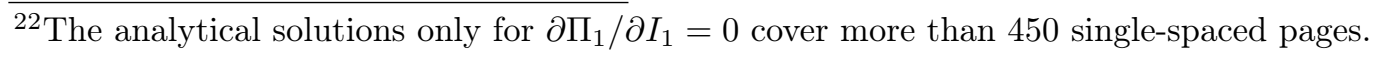


irrelevant for the investment decisions.

$$
\begin{aligned}
\frac{\partial \Pi_{i}\left(I_{1}, I_{2}, x\right)}{\partial I_{i}}= & \left(1-t_{i}\right)\left[\frac{I_{j}}{\left(I_{1}+I_{2}\right)^{2}}\left(\left(\frac{d}{\sqrt{x}}-\frac{a}{I_{1}}-\frac{a}{I_{2}}-2 k\right) x-I_{1}-I_{2}\right)\right. \\
& \left.+\frac{I_{i}}{I_{1}+I_{2}}\left(\frac{a x}{I_{i}^{2}}-1\right)\right] \\
= & \frac{1-t_{i}}{\left(I_{1}+I_{2}\right)^{2}}\left[I_{j}\left(\left(\frac{d}{\sqrt{x}}-\frac{a}{I_{1}}-\frac{a}{I_{2}}-2 k\right) x-I_{1}-I_{2}\right)\right. \\
& \left.+I_{i}\left(I_{1}+I_{2}\right)\left(\frac{a x}{I_{i}^{2}}-1\right)\right] \\
= & \frac{1-t_{i}}{\left(I_{1}+I_{2}\right)^{2}}\left[I_{j}\left(d \sqrt{x}-\frac{a x}{I_{1}}-\frac{a x}{I_{2}}-2 k x-I_{1}-I_{2}\right)\right. \\
& \left.+\left(I_{1}+I_{2}\right)\left(\frac{a x}{I_{i}}-I_{i}\right)\right] \\
= & \frac{1-t_{i}}{\left(I_{1}+I_{2}\right)^{2}}\left[I_{j}(d \sqrt{x}-2 k x)-\left(I_{1}+I_{2}\right)^{2}\right]=0 \\
= & I_{j}(d \sqrt{x}-2 k x) \\
I_{i}= & I_{i}\left(I_{j}\left(I_{i}\right)\right)=\sqrt{I_{j}(d \sqrt{x}-2 k x)}-I_{j} .
\end{aligned}
$$

As in the previous section, the subsidiaries' investment levels are inter-dependent, which is caused by the apportionment factor. Hence, the subsidiaries' investments have to be coordinated. This can be modelled by applying the concept of Nash equilibria with (49) representing the corresponding reaction functions. The first step to calculate the equilibrium is to conclude from (48) that equilibrium investments are equal due to the irrelevance of the tax rate and the symmetry of the subsidiaries:

$$
\begin{aligned}
\left(I_{1}+I_{2}\right)^{2} & =I_{j}(d \sqrt{x}-2 k x) \\
I_{1}(d \sqrt{x}-2 k x) & =I_{2}(d \sqrt{x}-2 k x) \\
I_{1} & =I_{2} .
\end{aligned}
$$

Second, inserting this result in the reaction functions (49)) yields:

$$
\begin{aligned}
I_{i} & =\sqrt{I_{i}(d \sqrt{x}-2 k x)}-I_{i} \\
4 I_{i}^{2} & =I_{i}(d \sqrt{x}-2 k x) \\
I_{i}^{*} & =\frac{d \sqrt{x}-2 k x}{4} .
\end{aligned}
$$


In principle, the optimal production quantity can be computed analytically using these optimal investment levels:

$$
\begin{aligned}
\Pi(x) & =\left(1-\frac{I_{1}}{I_{1}+I_{2}} t_{1}-\frac{I_{2}}{I_{1}+I_{2}} t_{2}\right)\left[\left(\frac{d}{\sqrt{x}}-\frac{a}{I_{1}}-\frac{a}{I_{2}}-2 k\right) x-I_{1}-I_{2}\right] \\
& =\left(1-\frac{t_{1}}{2}-\frac{t_{2}}{2}\right)\left[\left(\frac{d}{\sqrt{x}}-\frac{2 a}{\frac{d \sqrt{x}-2 k x}{4}}-2 k\right) x-\frac{d \sqrt{x}-2 k x}{2}\right] \\
& =\left(1-\frac{t_{1}}{2}-\frac{t_{2}}{2}\right)\left(\frac{d \sqrt{x}-2 k x}{2}-\frac{8 a x}{d \sqrt{x}-2 k x}\right) \\
& =\left(1-\frac{t_{1}}{2}-\frac{t_{2}}{2}\right)\left(\frac{d}{2} \sqrt{x}-k x-\frac{8 a x}{d \sqrt{x}-2 k x}\right) \\
\frac{d \Pi(x)}{d x} & =\left(1-\frac{t_{1}}{2}-\frac{t_{2}}{2}\right)\left[\frac{d}{4 \sqrt{x}}-k-\frac{8 a(d \sqrt{x}-2 k x)-8 a x\left(\frac{d}{2 \sqrt{x}-2 k}\right)}{(d \sqrt{x}-2 k x)^{2}}\right]=0 .
\end{aligned}
$$

Although the explicit expression for optimal quantity $x^{*}$ is too complicated to be displayed here, it can be seen from (53) that the optimal production quantity is unaffected by the tax rates and depends only on the pre-tax parameters $a, d$, and $k$. Moreover, it is undistorted compared to the pre-tax tax for given investment levels. However, note that due to tax-induced distortion of the optimal investment levels the optimal production quantity is altered compared to the previous sections as well. Thus, all kinds of economic decisions are distorted under a full-FA regime.

\subsection{Numerical Results}

For additional insight, this section provides a numerical comparison of the different tax allocation regimes under decentralized planning. The numerical results are based on the parameter setting introduced in Section 4.4:

$$
a=0.2, d=10, k=1, t_{1}=0.5, t_{2}=0.2, \tau=2 .
$$

Table 4 shows the optimal values in the pre-tax case and for transfer pricing which correspond to the optimal values under centralized planning. The two columns on the right hand side represent the results for allocation of taxes to subsidiaries' profits (Section 5.4) and full FA (Section 5.5). The optimal investment and production levels for profit sharing (Section 5.3) correspond to the transfer-pricing case and are not displayed 
separately.

\begin{tabular}{lcccc}
\hline & & \multicolumn{3}{c}{ tax } \\
& pre-tax & TP & allocation & full FA \\
\hline$I_{1}$ & 0.918 & 1.226 & 0.499 & 3.091 \\
$I_{2}$ & 0.918 & 1.226 & 0.731 & 3.091 \\
$I_{1}+I_{2}$ & 1.836 & 2.452 & 1.230 & 6.181 \\
$x$ & 4.214 & 7.512 & 4.273 & 5.008 \\
$\Pi$ & 8.428 & 5.259 & 5.435 & 3.597 \\
$p$ & 4.871 & 3.648 & 4.838 & 4.469 \\
$T_{1}$ & 0 & 1.210 & 1.626 & 1.383 \\
$T_{2}$ & 0 & 1.012 & 0.952 & 0.553 \\
$T_{1}+T_{2}$ & 0 & 2.222 & 2.579 & 1.937 \\
$\Pi+T_{1}+T_{2}$ & 8.428 & 7.481 & 8.014 & 5.533 \\
\hline
\end{tabular}

Table 4: Numerical examples for decentralized planning

Table 4 allows the following conclusions:

1. Comparing the results of Sections 5.4 and 5.5 one of the most striking results is that FA may induce underinvestment as well as overinvestment compared to the pre-tax case. This effect can be seen from total investment $I_{1}+I_{2}$.

2. In contrast to centralized planning, the investment levels in both countries coincide for full FA. If taxes based on FA are allocated to subsidiaries' profits, however, the low-tax country attracts more investment. Again, depending on the tax rate differential the investment levels may differ substantially. In all cases observed the investment levels under tax allocation decrease sharply, even for identical tax rates $t_{1}=t_{2}$.

3. In the cases depicted here the production quantity increases compared to the pretax case. However, this result cannot be generalized.

4. With regard to tax arbitrage the results from centralized planning apply.

5. The effects of the tax regime on total profit $\Pi$ are ambiguous. Hence, it is not clear whether switching to FA is desirable from a corporate perspective.

6. As under centralized planning the effects of the tax regime on total tax revenue, $T_{1}+T_{2}$, are ambiguous. There exist parameter settings under which both fiscal administrations may prefer TP with additional transfer payments between the countries compared to FA. 
7. Again, the effects of the tax regime on total value added are ambiguous.

\section{Conclusions and Implications}

As a contribution to the ongoing discussion on the possible introduction of FA in the European Union we analyze investment and production effects of different tax allocation regimes under various internal decision structures of a MNG. Under centralized as well as decentralized planning the effects of FA compared to TP are ambiguous. ${ }^{23}$ This qualitative result is valid with regard to

- total investment,

- production,

- total tax revenue, and

- total value added.

Apart from this general ambiguity the investment and production effects under decentralized planning differ substantially from those under centralized planning. The most striking result can be observed for full FA. Under decentralized planning this tax allocation regime induces identical investment levels in both countries irrespective of the tax rates. In contrast, the low-tax country attracts more investment if centralized planning is applied in the MNG.

Obviously, the MNG's decision structure has a decisive impact on the tax system's investment, production, tax revenue, and value added effects. The examples provided in this paper reveal that - depending on the decision procedure - FA may or may not violate neutrality. As a result, reliable forecasts of the effects of introducing FA are not possible unless the group's organizational structure is known. Since MNGs have no incentive to disclose their internal decision procedures, there is little chance to obtain useful predictions of the likely effects of FA. The results of the public finance literature concerning FA have to be interpreted in light of this constraint.

However, even if researchers had empirical results about MNGs' current internal decision structures the adjustments after a possible reform of the tax allocation regime would remain unknown. The reason for this problem is that MNGs' decision procedures are endogenous variables that depend on the tax framework. ${ }^{24}$ This insight complicates tax analyses dramatically: If the decision situation is tax-dependent it seems almost impossible to derive neutral tax systems that could serve as a yardstick to quantify tax

\footnotetext{
${ }^{23}$ The effects are summarized in Table 5

${ }^{24}$ See Nielsen/Raimondos-Møller/Schjelderup (2006).
} 
effects.

Table 5 gives an overview of the results derived throughout the paper. 


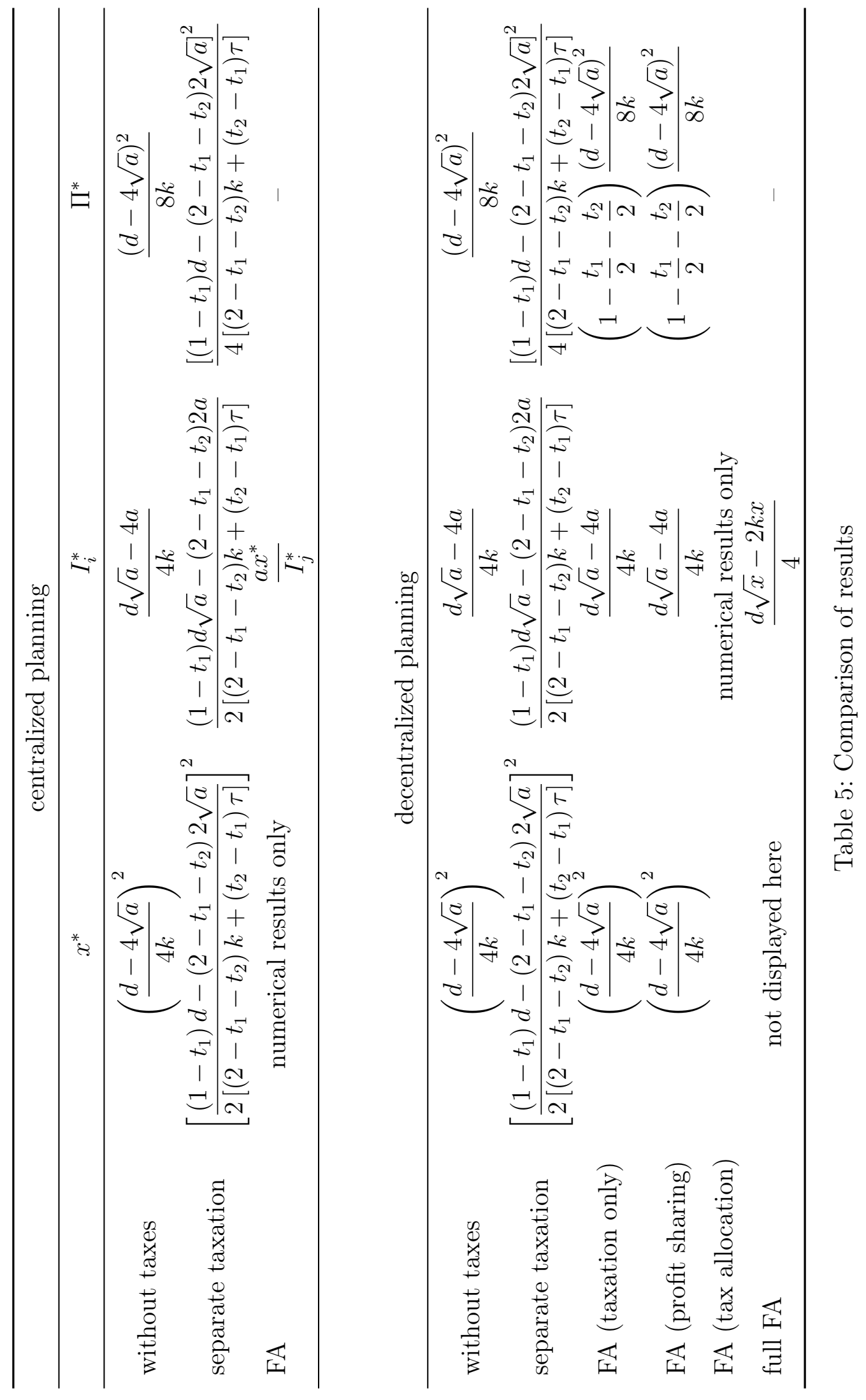




\section{Literature}

Anand, Bharat N./Sansing, Richard (2000): The Weighting Game: Formula Apportionment as an Instrument of Public Policy, in: National Tax Journal 53, 183-199.

Baldenius, Tim/Melumad, Nahum D./Reichelstein, Stefan (2004): Integrating Managerial and Tax Objectives in Transfer Pricing, in: The Accounting Review 79, 591-615.

Baldenius, Tim/Reichelstein, Stefan (2006): External and Internal Pricing in Multidivisional Firms, in: Journal of Accounting Research 44, 1-28.

Besanko, David/Sibley, David (1991): Compensation and Transfer Pricing in a Principal-Agent Model, in: International Economic Review 32, 55-68.

Bucks, Dan R./Mazerov, Michael (1993): The State Solution to the Federal Government's International Transfer Pricing Problem, in: National Tax Journal 46, 385392.

Choi, Yoon K./Day, Theodore E. (1998): Transfer Pricing, Incentive Compensation and Tax Avoidance in a Multi-Division Firm, in: Review of Quantitative Finance and Accounting 11, 139-164.

Chwolka, Anne/Simons, Dirk (2003): Impacts of Revenue Sharing, Profit Sharing, and Transfer Pricing on Quality-Improving Investments, in: European Accounting Review $12,47-76$.

Devereux, Michael P. (2004): Debating Proposed Reforms of the Taxation of Corporate Income in the European Union, in: International Tax and Public Finance 11, 71-89.

Elitzur, Ramy/Mintz, Jack (1996): Transfer Pricing Rules and Corporate Tax Competition, in: Journal of Public Economics 60, 401-422.

Ernst \&6 Young (ed.) (2001): Transfer Pricing 2001 Global Survey, Ernst \& Young International, Ltd.

European Commission (2001): Towards an Internal Market without Obstacles. A Strategy for Providing Companies for a Consolidated Tax Base for their EU-wide Activities, COM (2001) 582 final.

Fox, William F./Murray, Matthew N./Luna, LeAnn (2005): How Should a Subnational Corporate Income Tax on Multistate Businesses Be Structured?, in: National Tax Journal 58, 139-159.

Gérard, Marcel (2005): Multijurisdictional Firms and Governments' Strategies under Alternative Tax Designs, CESifo Working Paper No. 1527.

Gérard, Marcel/Weiner, Joann M. (2003): Cross-Border Loss Offset and Formulary Apportionment: How Do They Affect Multijurisdictional Firm Investment Spending and Interjurisdictional Tax Competition?, CESifo Working Paper No. 1004.

Goolsbee, Austan/Maydew, Edward L. (2000): Coveting Thy Neighbors's Manufacturing: The Dilemma of State Income Apportionment, in: Journal of Public Economics $75,125-143$.

Groves, Theodore M. (1973): Incentives in Teams, in: Econometrica 41, 617-631.

Groves, Theodore M./Loeb, Martin (1979): Incentives in a Divisionalized Firm, in: Management Science 25, 221-230. 
Göx, Robert/Schöndube, Jens Robert (2004): Strategic Transfer Pricing with Risk Averse Agents, Schmalenbachs Business Review 56, 98-118.

Gordon, Roger/Wilson, John D. (1986): An Examination of Multijurisdictional Corporate Income Taxation under Formula Apportionment, in: Econometrica 54, 13571373.

Grabski, Severin V. (1985), Transfer Pricing in Complex Organizations: A Review and Integration of Recent Empirical and Analytical Research, in: Journal of Accounting Literature 4, 33-75.

van Helleman, Johan/Slomp, Saskia (2002): The Changeover to International Accounting Standards in Europe, in: Betriebswirtschaftliche Forschung und Praxis 54, 213-229.

Hellerstein, Walter/McLure, Charles E. (2004): The European Commission's Report on Company Income Taxation: What the EU Can Learn from the Experience of the US States, in: International Tax and Public Finance 11, 199-220.

Horngren, Charles T./Datar, Srikant M./Foster, George (2006): Cost Accounting - A Managerial Emphasis, 12th ed., Prentice Hall, Upper Saddle River.

Hyde, Charles E./Choe, Chongwoo (2005): Keeping Two Sets of Books: The Relationship Between Tax and Incentive Transfer Prices, in: Journal of Economics \& Management Strategy 14, 165-186.

Klassen, Kenneth J./Lang, Mark/Wolfson, Mark (1993): Geographic Income Shifting by Multinational Corporations in Response to Tax Rate Changes, in: Journal of Accounting Research 31, 141-173.

Klassen, Kenneth J./Shackelford, Douglas A. (1998): State and Provincial Corporate Tax Planning: Income Shifting and Sales Apportionment Factor Management, in: Journal of Accounting and Economics 25, 385-406.

Lengsfeld, Stephan/Pfeiffer, Thomas/Schiller, Ulf (2006): Centralized versus Decentralized Transfer Pricing and Cost-System Choice, Working Paper, available at SSRN: http://ssrn. com/abstract $=925170$.

Li, Shu-Hsing/Balachandran, Kashi R. (1996): Effects of Differential Tax Rates on Transfer Pricing, in: Journal of Accounting, Auditing \& Finance 11, 183-196.

Martini, Jan Thomas (2006): Transfer Pricing for Coordination and Profit Determination, available at SSRN: http://ssrn. com/abstract=924545.

Martini, Jan Thomas/Chwolka, Anne/Simons, Dirk (2005): Accounting-Data-Based Transfer Prices in a Team-Investment Setting, Bielefeld University, Department of Business Administration and Economics, Discussion Paper No. 536.

McLure, Charles E./Weiner, Joann M. (2000): Deciding Whether the European Union Should Adopt Formula Apportionment of Company Income, in: Cnossen, Sijbren (ed.): Taxing Capital Income in the European Union - Issues and Options for Reform, Oxford University Press, Oxford, New York, 243-292.

Milgrom, Paul/Roberts, John (1992): Economics, Organization and Management, Prentice Hall, Englewood Cliffs.

Mintz, Jack/Smart, Michael (2004): Income Shifting, Investment, and Tax Competition: Theory and Evidence From Provincial Taxation in Canada, in: Journal of Public Economics 88, 1149-1168. 
Mintz, Jack/Weiner, Joann M. (2003): Exploring Formula Allocation for the European Union, in: International Tax and Public Finance 10, 695-711.

Musgrave, Peggy B. (1972): International Tax Base Division and the Multinational Corporation, in: Public Finance 27, 394-413.

Nielsen, Søren Bo/Raimondos-Møller, Pascalis/Schjelderup, Guttorm (2003): Formula Apportionment and Transfer Pricing under Oligopolistic Competition, in: Journal of Public Economic Theory 5, 419-437.

Nielsen, Søren Bo/Raimondos-Møller, Pascalis/Schjelderup, Guttorm (2006): Taxes and Decision Rights in Multinationals, CEPR Discussion Paper No. 5952.

Osband, Kent/Reichelstein, Stefan (1985): Information-Eliciting Compensation Schemes, in: Journal of Public Economics 27, 107-115.

Pethig, Rüdiger/Wagener, Andreas (2003): Profit Tax Competition and Formula Apportionment, CESifo Working Paper No. 1011.

Reichelstein, Stefan (1992): Constructing Incentive Schemes for Government Contracts: An Application of Agency Theory, in: The Accounting Review 67, 712-731.

Reichelstein Stefan/Osband, Kent (1984): Incentives in Government Contracts, in: Journal of Public Economics 24, 257-270.

Russo, Antonio (2005): Formulary Apportionment for Europe: An Analysis and a Proposal, in: Intertax 33, 2-31.

Samuelson, Larry (1982): The Multinational Firm with Arm's Length Transfer Price Limits, in: Journal of International Economics 13, 365-374.

Schäfer, Anne/Spengel, Christoph (2003): The Impact of ICT on Profit Allocation within Multinational Groups: Arm's Length Pricing or Formula Apportionment?, ZEW Discussion Paper No. 03-53.

Shackelford, Douglas/Slemrod, Joel (1998): The Revenue Consequences of Using Formula Apportionment to Calculate U.S. and Foreign-Source Income: A Firm-Level Analysis, in: International Tax and Public Finance 5, 41-59.

Simon, Hermann (1989): Price management, Elsevier Science, Amsterdam.

Simmons, Beth A. (2001): The International Politics of Harmonization: The Case of Capital Market Regulation, in: International Organization 55, 589-620.

Smith, Michael (2002): Tax and Incentive Trade-Offs in Multinational Transfer Pricing, in: Journal of Accounting, Auditing \& Finance 17, 209-236.

Sørensen, Peter Birch (2004): Company Tax Reform in the European Union, in: International Tax and Public Finance 11, 91-115.

Tang, Roger Y.W. (1993): Transfer Pricing in the 1990s: Tax and Management Perspectives, Quorum Books, Westport.

Tang, Roger Y.W. (2002): Current Trends and Corporate Cases in Transfer Pricing, Quorum Books, Westport.

U.S. Department of Commerce (2006): U.S. Goods Trade: Imports \& Exports by Related Parties - 2005, Press Release, http://www. census.gov

Wagenhofer, Alfred (1994): Transfer Pricing under Asymmetric Information, in: European Accounting Review 3, 71-104.

Weiner, Joann M. (2002): Would Introducing Formula Apportionment in the European Union Be a Dream Come True or the EU's Worst Nightmare?, in: ifo Studien 48, 
$519-532$.

Weitzman, Martin L. (1976): The New Soviet Incentive Model, in: Bell Journal of Economics 7, 251-257.

Wellisch, Dietmar (2004): Taxation under Formula Apportionment - Tax Competition, Tax Incidence, and the Choice of Apportionment Factors, in: FinanzArchiv 60, $24-41$.

Wildasin, David E. (2000): State and Provincial Corporate Income Taxation: Current Practice and Policy Issues for the United States and Canada, in: Canadian Tax Journal 48, 424-441.

Wong, Kar-yiu (1995): International Trade in Goods and Factor Mobility, Cambridge, Massachusetts.

Zimmerman, Jerold L. (2006): Accounting for decision making and control, 5th ed., McGraw-Hill/Irwin, Boston. 


\section{A Decentralized planning without taxes}

In a tax-free world, the group's profit function $\Pi$ reads

$$
\Pi\left(I_{1}, I_{2}, x\right)=\left(p(x)-c_{1}\left(I_{1}\right)-c_{2}\left(I_{2}\right)\right) x-I_{1}-I_{2} .
$$

The transfer price $\tau$ is used to divide the group's profit into the subsidiaries' profits $\Pi_{1}$ and $\Pi_{2}$ according to

$$
\Pi_{1}\left(I_{1}\right)=\left(\frac{d}{\sqrt{x}}-\frac{a}{I_{1}}-k_{1}-\tau\right) x-I_{1}
$$

and

$$
\Pi_{2}\left(I_{2}\right)=\left(\tau-\frac{a}{I_{2}}-k_{2}\right) x-I_{2} .
$$

Given these profits it is possible for the subsidiaries' managements to derive the optimal investment levels from the subsidiaries' perspective:

$$
\begin{aligned}
\frac{\partial \prod_{i}}{\partial I_{i}} & =\frac{a}{I_{i}^{2}} x-1=0 \\
I_{i}^{*} & =\sqrt{a x}
\end{aligned}
$$

Inserting the optimal investment levels into the group's profit function (54) gives:

$$
\begin{aligned}
\Pi(x) & =\left(\frac{d}{\sqrt{x}}-\frac{2 a}{\sqrt{a x}}-2 k\right) x-2 \sqrt{a x} \\
& =\sqrt{x}(d-4 \sqrt{a})-2 k x .
\end{aligned}
$$

The production quantity is still determined by the parent company. The derivative of (58) yields:

$$
\begin{aligned}
\frac{\partial \Pi(x)}{\partial x} & =\frac{1}{2 \sqrt{x}}(d-4 \sqrt{a})-2 k=0 \\
\frac{1}{2 \sqrt{x}}(d-4 \sqrt{a}) & =2 k \\
\sqrt{x} & =\frac{d-4 \sqrt{a}}{4 k} \\
x^{*} & =\left(\frac{d-4 \sqrt{a}}{4 k}\right)^{2} .
\end{aligned}
$$


The optimal production quantity corresponds to $x^{*}$ as derived in equation (10). The group's profit and investment levels are:

$$
\begin{aligned}
\Pi^{*} & =\sqrt{x}(d-4 \sqrt{a})-2 k x \\
& =\frac{(d-4 \sqrt{a} 4)^{2}}{4 k}-2 k\left(\frac{d-4 \sqrt{a}}{4 k}\right)^{2} \\
& =(d-4 \sqrt{a} 4)^{2}\left(\frac{1}{4 k}-\frac{2 k}{16 k^{2}}\right) \\
& =\frac{(d-4 \sqrt{a})^{2}}{8 k}>0 \\
I_{1}^{*} & =I_{2}^{*}=\sqrt{a x^{*}}=\frac{d \sqrt{a}-4 a}{4 k} .
\end{aligned}
$$

Obviously, the optimal investment levels are identical to the ones set by the parent company. Overall, optimal investment levels and production quantity are not affected by the transfer price $\tau$.

\section{B Decentralized planning under separate taxation}

Under separate taxation two different functions of transfer prices have to be considered, as they are needed to determine the tax bases of parent and subsidiaries independently. Neglecting taxation, transfer prices are a prerequisite for profit center organization as they allow to separate the subsidiaries' profits. According to current tax law both subsidiaries are taxed separately and are not allowed to file jointly. The transfer price is given exogenously as a comparable uncontrolled price. Hence, it cannot be optimized. Corresponding to (13) the profit functions of the subsidiaries are:

$$
\begin{aligned}
& \Pi_{1}\left(I_{1}\right)=\left(1-t_{1}\right)\left[\left(\frac{d}{\sqrt{x}}-\frac{a}{I_{1}}-k-\tau\right) x-I_{1}\right] \\
& \Pi_{2}\left(I_{2}\right)=\left(1-t_{2}\right)\left[\left(\tau-\frac{a}{I_{2}}-k\right) x-I_{2}\right] .
\end{aligned}
$$

Differentiating with respect to $I_{i}$ yields

$$
\begin{aligned}
\frac{\partial \Pi_{i}\left(I_{i}\right)}{\partial I_{i}} & =\left(1-t_{i}\right)\left(\frac{a x}{I_{i}^{2}}-1\right)=0 \\
I_{i}^{*} & =\sqrt{a x}
\end{aligned}
$$

which results from the tax-free case by multiplying by $\left(1-t_{i}\right)$. The investment decisions remain undistorted as the tax system fulfills the neutrality requirement here. However, inspecting the group's calculus shows that the production quantity $x$ is distorted. The 
profit function is:

$$
\begin{aligned}
\Pi(x)= & \left(1-t_{1}\right)\left[\left(\frac{d}{\sqrt{x}}-\frac{a}{I_{1}}-k-\tau\right) x-I_{1}\right]+\left(1-t_{2}\right)\left[\left(\tau-\frac{a}{I_{2}}-k\right) x-I_{2}\right] \\
= & \left(1-t_{1}\right)(d \sqrt{x}-2 \sqrt{a x}-k x-\tau x)+\left(1-t_{2}\right)(\tau x-2 \sqrt{a x}-k x) \\
= & \sqrt{x}\left[(d-2 \sqrt{a})\left(1-t_{1}\right)-2 \sqrt{a}\left(1-t_{2}\right)\right] \\
& +x\left[(-k-\tau)\left(1-t_{1}\right)+(\tau-k)\left(1-t_{2}\right)\right] .
\end{aligned}
$$

Differentiating (65) with respect to $x$ yields:

$$
\begin{aligned}
\frac{\partial \Pi(x)}{\partial x}= & \frac{1}{2 \sqrt{x}}\left[(d-2 \sqrt{a})\left(1-t_{1}\right)-2 \sqrt{a}\left(1-t_{2}\right)\right] \\
& +\left[(-k-\tau)\left(1-t_{1}\right)+(\tau-k)\left(1-t_{2}\right)\right]=0 \\
\sqrt{x}= & \frac{\left(1-t_{1}\right) d-2 \sqrt{a}\left(2-t_{1}-t_{2}\right)}{2\left[\left(2-t_{1}-t_{2}\right) k+\left(t_{2}-t_{1}\right) \tau\right]} \\
x^{*}= & \left(\frac{\left(1-t_{1}\right) d-2 \sqrt{a}\left(2-t_{1}-t_{2}\right)}{2\left[\left(2-t_{1}-t_{2}\right) k+\left(t_{2}-t_{1}\right) \tau\right]}\right)^{2} .
\end{aligned}
$$

As in the pre-tax case decentralized planning yields the same production quantity as centralized planning which was given by (17).

\section{Decentralized planning with tax allocation}

The parent company maximizes the after-tax profit $\Pi\left(I_{1}, I_{2}, x\right)$ given by

$$
\begin{aligned}
\Pi\left(I_{1}, I_{2}, x\right)= & \left(1-\frac{I_{1}}{I_{1}+I_{2}} t_{1}-\frac{I_{2}}{I_{1}+I_{2}} t_{2}\right) \\
& \cdot\left[\left(\frac{d}{\sqrt{x}}-\frac{a}{I_{1}}-\frac{a}{I_{2}}-2 k\right) x-I_{1}-I_{2}\right] \\
= & \left(1-\frac{I_{1}}{I_{1}+I_{2}} t_{1}-\frac{I_{2}}{I_{1}+I_{2}} t_{2}\right) \\
& \cdot\left(d \sqrt{x}-\frac{a x}{I_{1}}-\frac{a x}{I_{2}}-2 k x-I_{1}-I_{2}\right) \\
= & \Pi_{1}+\Pi_{2}
\end{aligned}
$$


with respect to quantity $x$ anticipating the subsidiaries' equilibrium investment reactions $I_{i}^{\Delta}(x)$ resulting from (43) and (45). The corresponding first-order condition reads:

$$
\begin{aligned}
\frac{d \Pi}{d x} & =\frac{\partial \Pi}{\partial I_{1}} \frac{d I_{1}^{\Delta}(x)}{d x}+\frac{\partial \Pi}{\partial I_{2}} \frac{d I_{2}^{\Delta}(x)}{d x}+\frac{\partial \Pi}{\partial x} \\
& =\frac{\partial \Pi_{1}}{\partial I_{1}} \frac{d I_{1}^{\Delta}(x)}{d x}+\frac{\partial \Pi_{2}}{\partial I_{1}} \frac{d I_{1}^{\Delta}(x)}{d x}+\frac{\partial \Pi_{1}}{\partial I_{2}} \frac{d I_{2}^{\Delta}(x)}{d x}+\frac{\partial \Pi_{2}}{\partial I_{2}} \frac{d I_{2}^{\Delta}(x)}{d x}+\frac{\partial \Pi_{1}}{\partial x}+\frac{\partial \Pi_{2}}{\partial x} \\
& =\left(\frac{\partial \Pi_{1}}{\partial I_{1}}+\frac{\partial \Pi_{2}}{\partial I_{1}}\right) \frac{d I_{1}^{\Delta}(x)}{d x}+\left(\frac{\partial \Pi_{1}}{\partial I_{2}}+\frac{\partial \Pi_{2}}{\partial I_{2}}\right) \frac{d I_{2}^{\Delta}(x)}{d x}+\frac{\partial \Pi_{1}}{\partial x}+\frac{\partial \Pi_{2}}{\partial x}=0 .
\end{aligned}
$$

Unfortunately, analytical solutions of $I_{i}^{\Delta}(x)$ and thus for (69) are prohibitively complicated. Even a straight numerical solution approach using standard software tools is likely to be infeasible. Nevertheless, it is possible to derive optimal results numerically by following two steps. First, exploit the fact that the partial derivatives $\partial \Pi_{i} / \partial I_{i}$ vanish according to (43) and (45) which simplifies (69) considerably. Second, apply the implicit function theorem to restate the subsidiaries' equilibrium investment reactions to quantity $x$ :

$$
\frac{d I_{i}^{\Delta}(x)}{d x}=-\frac{\frac{\partial^{2} \Pi_{i}}{\partial I_{i} \partial x}}{\frac{\partial^{2} \Pi_{i}}{\partial I_{i} \partial I_{i}}}
$$

In total, this results in the following system of equations that has to be solved numerically for $I_{1}, I_{2}$, and $x$ :

$$
\frac{\partial \Pi_{1}}{\partial I_{1}}=\frac{\partial \Pi_{2}}{\partial I_{2}}=\frac{\partial \Pi_{1}}{\partial x}+\frac{\partial \Pi_{2}}{\partial x}-\frac{\partial \Pi_{2}}{\partial I_{1}} \frac{\frac{\partial^{2} \Pi_{1}}{\partial I_{1} \partial x}}{\frac{\partial^{2} \Pi_{1}}{\partial I_{1} \partial I_{1}}}-\frac{\partial \Pi_{1}}{\partial I_{2}} \frac{\frac{\partial^{2} \Pi_{2}}{\partial I_{2} \partial x}}{\frac{\partial^{2} \Pi_{2}}{\partial I_{2} \partial I_{2}}}=0 .
$$




\section{CESifo Working Paper Series}

(for full list see www.cesifo-group.de)

1956 Panu Poutvaara and Lars-H. R. Siemers, Smoking and Social Interaction, March 2007

1957 Stephan Danninger and Fred Joutz, What Explains Germany's Rebounding Export Market Share?, March 2007

1958 Stefan Krasa and Mattias Polborn, Majority-efficiency and Competition-efficiency in a Binary Policy Model, March 2007

1959 Thiess Buettner and Georg Wamser, Intercompany Loans and Profit Shifting Evidence from Company-Level Data, March 2007

1960 Per Pettersson-Lidbom and Mikael Priks, Behavior under Social Pressure: Empty Italian Stadiums and Referee Bias, April 2007

1961 Balázs Égert and Carol S. Leonard, Dutch Disease Scare in Kazakhstan: Is it real?, April 2007

1962 Paul De Grauwe and Pablo Rovira Kaltwasser, Modeling Optimism and Pessimism in the Foreign Exchange Market, April 2007

1963 Volker Grossmann and Thomas M. Steger, Anti-Competitive Conduct, In-House R\&D, and Growth, April 2007

1964 Steven Brakman and Charles van Marrewijk, It's a Big World After All, April 2007

1965 Mauro Ghinamo, Paolo M. Panteghini and Federico Revelli, FDI Determination and Corporate Tax Competition in a Volatile World, April 2007

1966 Inés Macho-Stadler and David Pérez-Castrillo, Optimal Monitoring to Implement Clean Technologies when Pollution is Random, April 2007

1967 Thomas Eichner and Ruediger Pethig, Efficient $\mathrm{CO}_{2}$ Emissions Control with National Emissions Taxes and International Emissions Trading, April 2007

1968 Michela Redoano, Does Centralization Affect the Number and Size of Lobbies?, April 2007

1969 Christian Gollier, Intergenerational Risk-Sharing and Risk-Taking of a Pension Fund, April 2007

1970 Swapan K. Bhattacharya and Biswa N. Bhattacharyay, Gains and Losses of India-China Trade Cooperation - a Gravity Model Impact Analysis, April 2007

1971 Gerhard Illing, Financial Stability and Monetary Policy - A Framework, April 2007 
1972 Rainald Borck and Matthias Wrede, Commuting Subsidies with two Transport Modes, April 2007

1973 Frederick van der Ploeg, Prudent Budgetary Policy: Political Economy of Precautionary Taxation, April 2007

1974 Ben J. Heijdra and Ward E. Romp, Retirement, Pensions, and Ageing, April 2007

1975 Scott Alan Carson, Health during Industrialization: Evidence from the $19^{\text {th }}$ Century Pennsylvania State Prison System, April 2007

1976 Andreas Haufler and Ian Wooton, Competition for Firms in an Oligopolistic Industry: Do Firms or Countries Have to Pay?, April 2007

1977 Eckhard Janeba, Exports, Unemployment and the Welfare State, April 2007

1978 Gernot Doppelhofer and Melvyn Weeks, Jointness of Growth Determinants, April 2007

1979 Edith Sand and Assaf Razin, The Role of Immigration in Sustaining the Social Security System: A Political Economy Approach, April 2007

1980 Marco Pagano and Giovanni Immordino, Optimal Regulation of Auditing, May 2007

1981 Ludger Woessmann, Fundamental Determinants of School Efficiency and Equity: German States as a Microcosm for OECD Countries, May 2007

1982 Bas Jacobs, Real Options and Human Capital Investment, May 2007

1983 Steinar Holden and Fredrik Wulfsberg, Are Real Wages Rigid Downwards?, May 2007

1984 Cheng Hsiao, M. Hashem Pesaran and Andreas Pick, Diagnostic Tests of Cross Section Independence for Nonlinear Panel Data Models, May 2007

1985 Luis Otávio Façanha and Marcelo Resende, Hierarchical Structure in Brazilian Industrial Firms: An Econometric Study, May 2007

1986 Ondřej Schneider, The EU Budget Dispute - A Blessing in Disguise?, May2007

1987 Sascha O. Becker and Ludger Woessmann, Was Weber Wrong? A Human Capital Theory of Protestant Economic History, May 2007

1988 Erkki Koskela and Rune Stenbacka, Equilibrium Unemployment with Outsourcing and Wage Solidarity under Labour Market Imperfections, May 2007

1989 Guglielmo Maria Caporale, Juncal Cunado and Luis A. Gil-Alana, Deterministic versus Stochastic Seasonal Fractional Integration and Structural Breaks, May 2007

1990 Cláudia Costa Storti and Paul De Grauwe, Globalization and the Price Decline of Illicit Drugs, May 2007 
1991 Thomas Eichner and Ruediger Pethig, Pricing the Ecosystem and Taxing Ecosystem Services: A General Equilibrium Approach, May 2007

1992 Wladimir Raymond, Pierre Mohnen, Franz Palm and Sybrand Schim van der Loeff, The Behavior of the Maximum Likelihood Estimator of Dynamic Panel Data Sample Selection Models, May 2007

1993 Fahad Khalil, Jacques Lawarrée and Sungho Yun, Bribery vs. Extortion: Allowing the Lesser of two Evils, May 2007

1994 Thorvaldur Gylfason, The International Economics of Natural Resources and Growth, May 2007

1995 Catherine Roux and Thomas von Ungern-Sternberg, Leniency Programs in a Multimarket Setting: Amnesty Plus and Penalty Plus, May 2007

1996 J. Atsu Amegashie, Bazoumana Ouattara and Eric Strobl, Moral Hazard and the Composition of Transfers: Theory with an Application to Foreign Aid, May 2007

1997 Wolfgang Buchholz and Wolfgang Peters, Equal Sacrifice and Fair Burden Sharing in a Public Goods Economy, May 2007

1998 Robert S. Chirinko and Debdulal Mallick, The Fisher/Cobb-Douglas Paradox, Factor Shares, and Cointegration, May 2007

1999 Petra M. Geraats, Political Pressures and Monetary Mystique, May 2007

2000 Hartmut Egger and Udo Kreickemeier, Firm Heterogeneity and the Labour Market Effects of Trade Liberalisation, May 2007

2001 Andreas Freytag and Friedrich Schneider, Monetary Commitment, Institutional Constraints and Inflation: Empirical Evidence for OECD Countries since the 1970s, May 2007

2002 Niclas Berggren, Henrik Jordahl and Panu Poutvaara, The Looks of a Winner: Beauty, Gender, and Electoral Success, May 2007

2003 Tomer Blumkin, Yoram Margalioth and Efraim Sadka, Incorporating Affirmative Action into the Welfare State, May 2007

2004 Harrie A. A. Verbon, Migrating Football Players, Transfer Fees and Migration Controls, May 2007

2005 Helmuth Cremer, Jean-Marie Lozachmeur and Pierre Pestieau, Income Taxation of Couples and the Tax Unit Choice, May 2007

2006 Michele Moretto and Paolo M. Panteghini, Preemption, Start-Up Decisions and the Firms' Capital Structure, May 2007 
2007 Andreas Schäfer and Thomas M. Steger, Macroeconomic Consequences of Distributional Conflicts, May 2007

2008 Mikael Priks, Judiciaries in Corrupt Societies, June 2007

2009 Steinar Holden and Fredrik Wulfsberg, Downward Nominal Wage Rigidity in the OECD, June 2007

2010 Emmanuel Dhyne, Catherine Fuss, Hashem Pesaran and Patrick Sevestre, Lumpy Price Adjustments: A Microeconometric Analysis, June 2007

2011 Paul Belleflamme and Eric Toulemonde, Negative Intra-Group Externalities in TwoSided Markets, June 2007

2012 Carlos Alós-Ferrer, Georg Kirchsteiger and Markus Walzl, On the Evolution of Market Institutions: The Platform Design Paradox, June 2007

2013 Axel Dreher and Martin Gassebner, Greasing the Wheels of Entrepreneurship? The Impact of Regulations and Corruption on Firm Entry, June 2007

2014 Dominique Demougin and Claude Fluet, Rules of Proof, Courts, and Incentives, June 2007

2015 Stefan Lachenmaier and Horst Rottmann, Effects of Innovation on Employment: A Dynamic Panel Analysis, June 2007

2016 Torsten Persson and Guido Tabellini, The Growth Effect of Democracy: Is it Heterogenous and how can it be Estimated?, June 2007

2017 Lorenz Blume, Jens Müller, Stefan Voigt and Carsten Wolf, The Economic Effects of Constitutions: Replicating - and Extending - Persson and Tabellini, June 2007

2018 Hartmut Egger and Gabriel Felbermayr, Endogenous Skill Formation and the Source Country Effects of International Labor Market Integration, June 2007

2019 Bruno Frey, Overprotected Politicians, June 2007

2020 Jan Thomas Martini, Rainer Niemann and Dirk Simons, Transfer Pricing or Formula Apportionment? Tax-Induced Distortions of Multinationals' Investment and Production Decisions, June 2007 